EISSN: 2706-7955 ISSN: 2077-4605

DOI: $10.36632 /$ mejar/2021.10.2.44

Journal homepage: www.curresweb.com

Pages: 588-603

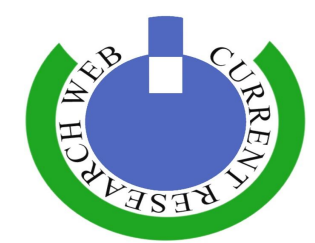

\title{
Effect of Nitrogen Mineral Fertilizer, Vermicompost and Biofertilizer on Lettuce Yield and Quality
}

Fatma Sayed Aboud ${ }^{1}$ and Hanaa A. Abd-Alrahman ${ }^{2}$

${ }^{1}$ Central Laboratory for Agricultural Climate (CLAC), Agriculture Research Center, Giza, Egypt.

${ }^{2}$ Department of Vegetable Research, National Research Centre (NRC), 33 El-Buhouth St., 12622 Dokki, Giza, Egypt.

Received: 20 April $2021 \quad$ Accepted: 15 May $2021 \quad$ Published: 30 May 2021

\begin{abstract}
Lettuce (Lactuca sativa $\mathrm{L}$ ) is one of the most consumed vegetable worldwide due to its richness in vitamins, minerals and fibers content. This study was conducted to evaluate the effect of bio, nitrogen mineral and organic fertilizers and their interactions on the growth, mineral content of leaves, yield and quality of lettuce plants. Three treatments of nitrogen fixing microorganisms (Aztobacter chroococcum, Azospirillum brasilense and control). Four equations of nitrogen mineral and/or organic fertilizers were applied $(100 \%$ mineral, $50 \%$ mineral $+50 \%$ vermicompost, $25 \%$ mineral $+75 \%$ vermicompost and $100 \%$ vermicompost) of the recommended fertilizer unit. Results showed that Azotobacter chroococcum recorded the highest values of growth, total yield, leaves mineral content, i.e., N, P, K, $\mathrm{Ca}$ and nutritional value (carbohydrates and vitamin $\mathrm{C}$ ) as well as lower nitrate content compared with control (without bio-fertilizers). Equation of $100 \%$ vermincompost of the recommended fertilizer unit exhibited the highest values of vegetative growth, leaves mineral content, yield, leaves nutritional value and lower values of nitrate content compared to the other treatments. The combined effect of Azotobacter chroococcum with $100 \%$ vermicompost of the recommended fertilizer units recorded the maximum values of the pre-mentioned parameters.
\end{abstract}

Keywords: Lettuce, bio-fertilizers, nitrogen mineral fertilizers, organic fertilizers, vermi-compost, yield, nutritional value, mineral content.

\section{Introduction}

Lettuce (Lactuca sativa $\mathrm{L}$ ) is rich in vitamins, minerals and fibers content which is cultivated and consumed worldwide. Stevens (1974) ranked lettuce as the 26th according to its nutritive value and the 4 th in terms of consumption. Its high nutritional value motivates many researchers to study and investigate its physical and chemical composition in trials to enhance and promote its productivity (Moreira et al., 2014; Christopoulou et al. 2015; Amoozgar et al., 2017 and Ghosh and Devi 2019). According to the United States Department of Agriculture (USDA) nutrient database (2015), lettuce is among the healthy crops as it is a rich source of phenolic compounds, b-carotene, and lutein content which plays a considerable role in reducing risk of cancers, cataracts and heart disease and stroke. López et al. (2014) reported that carotenoids possess an anti-oxidant capacity. One of the medical facts is that meals rich in dietary fibers has positive effects on the functioning of the digestive system (Mampholo et al., 2016). Lettuce is a leafy vegetable which very sensitive to the environmental conditions such as weather, water stresses and fertilization (Alisson et al., 2017). Lettuce is low-calorie salad plant is a good source of foliate and vitamins (A, C, K) (IBGE, 2013; Hasan et al., 2017).

Lettuce has loosely bunched leaves and is used mainly for salads (Hamerschmidt et al., 2013). It is sensitive to Nitrogen fertilization, as lettuce yield increases with $\mathrm{N}$ fertilization increase. This may yield in a higher profit as a favorable result. However, excessive $\mathrm{N}$ fertilizer application may cause the accumulation of $\mathrm{NO}_{3}{ }^{-}$in the leaves which reduces the quality of lettuce (Liu et al., 2014 and Qiu et al., 2014). So, proper fertilization management requires wise use of $\mathrm{N}$ fertilizers so maximum yield is

Corresponding Author: Fatma Sayed Aboud, Central Laboratory for Agricultural Climate (CLAC), Agriculture Research Center, Giza, Egypt. Email: batta_fatma2@yahoo.com 
achieved and crop development is maintained, whilst economic inefficiencies and environmental contamination caused by nitrate $\left(\mathrm{NO}_{3}{ }^{-}\right)$leaching to groundwater is reduced (Dahan et al., 2014). Nitrate might not be toxic; however, when it is transformed to nitrite, the toxicity increases, as the probability of formation of toxic compounds increases. The reason behind this is the ability of nitrite to react with amines and amides compounds forming $\mathrm{N}$-nitroso compounds. These N-nitroso compounds have been correlated to a high risk of diseases, such as the blood diseases (Santamaria, 2006). In addition, nitrite may react with certain amine and form nitrosamines, which are potent cancer-causing substances. In this regard, many researchers put more effort reducing nitrate levels in vegetables with more concern with leafy vegetables such as lettuce (Liu et al., 2014 and Resende et al., 2010). The application of organic fertilizers decreased the nitrate concentration in heads of lettuce plants (Bosch et al., 1991). Moreover, it increases the agro ecosystems long-term sustainability (Mehnaz and Lazarovits, 2006). As a matter of fact, organic farming produces lower nitrate concentration vegetable crops (Bosch et al., 1991; Williams, 2002; Mehnaz and Lazarovits, 2006).

The increasing cost and the negative environmental impacts of nitrogen mineral fertilizers boosted the use bio-fertilizers as an alternative source. Bio-fertilizers are beneficial microorganisms known for their antifungal activities, increase seeds germination, improve plants vigor, and increases plant diseases resistance which contribute to the improvement of plant development and production (Moradi et al., 2011; Shirkhodaei et al., 2014; Khalil et al., 2019). In addition, the production technology for biofertilizers is relatively simple and the installation cost is very low compared to chemical fertilizer plants (Dawa et al. 2012; Fawzy et al., 2012: Ahmed et al., 2012, Abdel-Razzak, and EI-Sharkawy, 2013, Abou El-Magd et al., 2014 ; Zaki et al., 2014 and Hassan, 2015). Azotobacter chroococcum and Azospirillum are among the widely used biofertilizers for many plants such as maize, wheat, sorghum and rice. Azospirillum been known by its associative nitrogen fixing role. Azospirillum is aerobic bacterium that can thrive in flooded conditions (Sahoo et al., 2014). It promotes various aspects of plant growth and development (Bhattacharyya, 2012). Ardakani et al. (2011) found that inoculating wheat seeds with Azospirillum increased plant $\mathrm{N}$ absorption by $21.68 \%$.

Naturally cofound minerals, manure, animal waste, compost and vermin-compost are forms of organic fertilizers that can be used in organic farming. However, compost is commonly used as it is very rich in organic matter and minerals. Organic fertilizers are cost effective and eco-friendly which have a great prospect of supplying nutrients which can reduce over-dependence on chemical fertilizer (Bajeli et al., 2016). Organic fertilizers exist in many forms and names. Among them is Vermi-compost which is created by the interactions between earthworm, microorganisms and organic residuals. Vermicomposting has many economically and environmentally benefits (Eswaran and Mariselvi, 2016). It enhances plant growth and development directly and indirectly through the improvement of soil physical and chemical properties such as porosity and water holding capacity (Pandya et al., 2014; Marc et al., 2015). Organic wastes converted to Vermicompost have beneficial effects on plant growth and development. It improves seedling vigor, and plant growth by increasing humic acid and consequently increases plant growth hormones (Gopalakrishnan et al. 2012; Alsina et al. 2013).

The objective of this study was to evaluate the growth response of lettuce plants treated with nitrogen mineral and/ or organic and biofertilizer, and then to compare them with the traditional chemical fertilizer.

\section{Materials and Methods}

This study was carried out during the two successive seasons of 2018/2019 and 2019/2020 in a net-house located in the Central Laboratory of Agricultural Climate Research Centre (CLAC), Dokki, Giza, Egypt. This work aimed to study the effect of nitrogen mineral, vermin-compost and bio fertilizers on the growth, chemical characteristics and yield of lettuce plants (Lactuca sativa, L.) under the conditions of clay soil using drip irrigation system. Soil and irrigation water characteristics were determined by analyzing a representative surface soil sample $(0-30 \mathrm{~cm})$ and irrigation water according to the procedures determined by Jackson (1973) and illustrated in Table (1). 
Table 1: Physical and chemical properties of a representative soil sample used in the experimental site and irrigation water

\begin{tabular}{|c|c|c|c|c|c|c|c|c|}
\hline \multirow{2}{*}{$\begin{array}{c}\text { pH 1:1 } \\
\text { suspension }\end{array}$} & \multirow{2}{*}{$\begin{array}{c}\text { EC } \\
(1: 1 \text { extract) } \\
\text { dsm }^{-1}\end{array}$} & & \multicolumn{4}{|c|}{ Soluble cations (\%) } & \multicolumn{2}{|c|}{ Soluble anions (\%) } \\
\hline & & & $\mathrm{Ca}^{+2}$ & $\mathbf{M g}^{+2}$ & $\mathbf{N a}^{+1}$ & $\mathrm{~K}^{+1}$ & $\mathrm{CO}_{3}+\mathrm{HCO}_{3}$ & $\mathrm{Cl}^{-}$ \\
\hline 7.8 & 1.5 & & 7.3 & 1.6 & 4.3 & 1.2 & 1.4 & 2.3 \\
\hline \multicolumn{3}{|c|}{ Soil available nutrients (ppm) } & \multicolumn{6}{|c|}{ Soil mechanical analysis \% } \\
\hline N (ppm) & $P(p p m)$ & K (ppm) & \multicolumn{2}{|c|}{ Coarse Sand } & $\begin{array}{l}\text { Fine } \\
\text { Sand }\end{array}$ & Silt & Clay & $\begin{array}{l}\text { Texture } \\
\text { class }\end{array}$ \\
\hline 15.6 & 12.7 & 33.4 & \multicolumn{2}{|c|}{3.2} & 17.3 & 19.9 & 59.6 & Clay \\
\hline \multicolumn{9}{|c|}{ Irrigation water } \\
\hline PH & EC & $\mathrm{Ca}^{+2}$ & $\mathbf{M g}^{+2}$ & $\mathbf{N a}^{+1}$ & $\overline{\mathrm{K}^{+1}}$ & $\mathrm{HCO}_{3}^{-}$ & $\mathrm{Cl}^{-}$ & $\mathrm{SO}_{4}^{--}$ \\
\hline 7.4 & 1.2 & 8.5 & 3.6 & 3.2 & 0.2 & 6.3 & 2.2 & 7.2 \\
\hline
\end{tabular}

\subsection{Plant material}

Seedlings were transplanted during the first week of Octobers 2018 and 2019 in both seasons. Seedlings were obtained from the Central Laboratory of Agricultural Climate Research Centre (CLAC), Dokki, Giza, Egypt. Seedlings were placed in double rows beds. Ditches of $20 \mathrm{~cm}$ width and $20 \mathrm{~cm}$ depth were prepared besides every irrigation line. Organic fertilizers (vermin-compost was used as a nitrogen source), calcium super phosphate at a rate of $90 \mathrm{Kg} / \mathrm{fed}$. and agricultural sulphur at a rate of $100 \mathrm{Kg}$ per fed. were spread through the ditches and covered by sand. Drip irrigation lines were established over the ditches and soil was irrigated continuously three days before transplanting. Needed horticultural practices were applied. Potassium sulfate $\left(48 \% \mathrm{~K}_{2} \mathrm{O}\right)$ at a rate of $60 \mathrm{~K}_{2} \mathrm{O}$ units/fed were applied during both growing seasons through irrigation system.

Four equations of nitrogen mineral and/or organic fertilizers were applied (100\% mineral, $50 \%$ mineral $+50 \%$ vermicompost, $25 \%$ mineral $+75 \%$ vermicompost and $100 \%$ vermicompost) of the recommended fertilizer unit. Organic fertilizers (vermicompost was used as a nitrogen source) and added during soil preparation before the season start. The physical and chemical composition of the used vermicompost are listed in table (2). Nitrogen source of mineral fertilizer in the form of ammonium sulfate $(21.5 \% \mathrm{~N})$ were applied during all growing seasons and were stopped two weeks before harvest. Azotobacter chroococcum and Azospirillum brasilense treatments as a bio-fertilizer were applied by injection trough the irrigation water.

Table 2: Vermicompost physical and chemical properties:

\begin{tabular}{ccccccccc}
\hline $\mathbf{p H}$ & $\begin{array}{c}\mathbf{E C} \\
\left(\mathbf{d s} \cdot \mathbf{m}^{-\mathbf{1}}\right)\end{array}$ & $\begin{array}{c}\text { Organic matter } \\
(\mathbf{\%})\end{array}$ & $\begin{array}{c}\text { Total N } \\
\mathbf{( \% )}\end{array}$ & $\begin{array}{c}\text { Total P } \\
\mathbf{( \% )}\end{array}$ & $\begin{array}{c}\text { Total K } \\
(\mathbf{\%})\end{array}$ & $\begin{array}{c}\mathbf{F e} \\
(\mathbf{p p m})\end{array}$ & $\begin{array}{c}\text { Mn } \\
(\mathbf{p p m})\end{array}$ & $\begin{array}{c}\mathbf{Z n} \\
(\mathbf{p p m})\end{array}$ \\
\hline 7.4 & 6.3 & 55 & 2.18 & 0.53 & 1.53 & 821 & 145 & 44 \\
\hline
\end{tabular}

\subsection{Preparing of biofertilizers}

The nitrogen fixer's bacteria (Azotobacter chroococcum and Azospirillum brasilense) were isolated locally obtained from the National Research Centre, Dokki, Cairo, Egypt. The $\mathrm{N}_{2}$ fixer's cultures containing $5 \mathrm{X} 106 \mathrm{cfu} / \mathrm{ml}$. were used $50 \mathrm{ml}$. of each bacterial strain and diluted as 1:10 ml.

\section{The experimental design and treatments:}

The experiment was arranged in a randomized split plot design with three replicates where the bio-fertilizer contributed as the main plot, while organic fertilizer and mineral fertilizer were distributed in the sub- plots $(3 * 4 * 3)$. Every treatment contained three replicates.

The experiment included two factors as follow:

\section{The first factor: bio-fertilizer treatments}

Three bio fertilizers were tested and without inoculation treatment as following:

1- Without: Without bio-fertilizer

2- Aztobacter chroococcum

3- Azospirillum brasilense

Bio-fertilizer treatments were applied three times after 2, 4 and 6 weeks of transplanting, respectively. 
The second factor: for mineral and organic fertilization ratios:

$1-100 \%$ mineral of the recommended fertilizer units ( 90 Unit nitrogen/fadden).

2- $50 \%$ mineral $+50 \%$ vermicompost (of the recommended fertilizer units).

$3-25 \%$ mineral $+75 \%$ vermicompost (of the recommended fertilizer units).

4- 100\% vermicompost (of the recommended fertilizer units).

\subsection{Data collection and measurements}

2.3.1. Vegetative growth parameters:

At 75 days from transplanting a random sample of three plants were taken from each experimental unit for measuring plant length $(\mathrm{cm})$, number of leaves per plant, as well as plant fresh weight $(\mathrm{g})$, head weight $(\mathrm{g})$, head length $(\mathrm{cm})$, and head width $(\mathrm{cm})$. Dry matter was determined by allowing $100 \mathrm{~g}$ fresh leaves to dry in a hot air oven at $105^{\circ} \mathrm{C}$ until constant weight and dry matter $\%$ was determined.

Yield and its components: At harvest time (100 days after transplanting) the fresh heads of lettuce of each plot were harvested, then weighted to determine average head weight and total yield per feddan.

\subsection{Chemical analysis:}

\subsubsection{Determination of leaf mineral contents $(\mathrm{N}, \mathrm{P}, \mathrm{K}$ and $\mathrm{Ca} \%)$}

A dried sample of $0.5 \mathrm{~g}$ was taken in $500 \mathrm{ml}$ kejldahl flask, then $10 \mathrm{ml}$ of Conc. $\mathrm{H}_{2} \mathrm{SO}_{4}$ were added and digested till colorless solution appeared. The content was cooled down and diluted to about $25 \mathrm{ml}$ with distilled water (solution 1). Determinations of total nitrogen in solution (1) according to kejldahl method as Motsara and Roy (2008), Total phosphorus was determined colorimetrically by ascorbic acid reductant method according to Motsara and Roy (2008) as modified by Watanabe and Olsen, (1965), and Total potassium was determined in solution (1) by using flame photometer according to A.O.A.C, (1990) and calcium were determined spectrometrically using a Phillips Unicom Atomic Absorption spectrophotometer as described by Chapman and Pratt (1982).

\subsection{Determination of nutritional value}

- Ascorbic acid (Vit. C) was determined in $\mathrm{mg} / 100 \mathrm{~g}$ fresh weight by using 2, 6 dichlorophenol indophenol for titration according to A.O.A.C (1990).

- Total carbohydrate percentage was determined in leaves according to A.O.A.C. (1990).

- Crude protein: The nitrogen content in heads was estimated by modified Kjeldahl's methods A.O.A.C. (1990). The protein content was calculated by multiplying nitrogen percentage with a factor 6.25 (Tai and Young, 1974).

- Nitrate determination: Nitrate extraction, and chemical determination using salicylic acid by (Cataldo et al., 1975).

\subsection{Statistical analysis}

Data of the experiment was statistically analyzed using Mstatic (M.S.) software. The comparison among means of the different treatments was determined as illustrated by Snedecor and Cochran (1982). Means followed by the same alphabetical letters are not statistical different at $5 \%$ level of significance according to (Duncan, 1955).

\section{Results and Discussion}

\subsection{Effect of different fertilizer sources on vegetative growth characteristics:}

Data illustrated in Table (3) shows the effect of different fertilizer treatments on plant length $(\mathrm{cm})$, number of leaves, plant fresh weight $(\mathrm{g})$ and plant dry matter $(\%)$ of lettuce plants. The application of biofertilizer significantly enhanced lettuce vegetative characteristics compared to the control (without biofertilizer) treatments during the two seasons. Data in table (3a) also indicates that the application of Azotobacter chroococcum was superior in plant growth characters followed by the application of Azospirillum brasilense for the two seasons compared to the control treatment. Number of leaves per plant were also significantly increased from about 22 leaf/plant in case of control to about 33 leaf/plant in case of Azotobacter chroococcum. While lettuce plant fresh weight increased from 775.75 and 871.28 in case of the control treatment to 837.17 and 929.17 in case of Azotobacter 
chroococcum application in both seasons respectively. The highest values of plant dry matter were recorded by Azotobacter chroococcum treatment followed by Azospirillium treatment.

Speaking about the effect of nitrogen mineral and vermi-compost, data in table (3b) reveal that the application of $100 \%$ vermicompost of the recommended fertilizer unit treatment was superior in plant growth characters (plant length, leaves number/plant, plant fresh and dry matter) to all other fertilizers mixture this was followed by the $25 \%$ mineral $+75 \%$ vermi-compost of the recommended fertilizer unit requirements in clay soils with no significant differences among them for both seasons. the application of mineral fertilizer at the recommended dose came at the last order among all other treatments in both seasons with a significant decrease in all studied vegetative parameters.

In table (3c) the interaction effect of bio, mineral and organic fertilizers on plant growth. The application of Azotobacter chroococcum in combination with 100\% vermicompost of the recommended fertilizer unit was superior among all other treatments in both seasons in all vegetative growth parameters. The application of this mixture of Azotobacter chroococcum and vermicompost significantly increased plant length to $44.67,43.00$, also increased number of leaves per plant to 42.67 , 43.67, plant fresh weight to $909.33,994.33$ (g/plant) and plant dry matter (\%) 21.73, 22.93 in both seasons respectively. It is noticeable that the application of bio-fertilizer enhanced significantly plant vegetative characters compared to the case of not adding them. The lowest values were recorded in case of mineral fertilizer at $100 \%$ of the recommended unit.

Table 3: Effect of mineral nitrogen, vermi-compost and bio-fertilizer and their interaction on lettuce vegetative characteristics during 2018/2019 and 2019/2020 seasons.

\begin{tabular}{|c|c|c|c|c|c|c|c|c|c|}
\hline \multirow{2}{*}{ Treatments } & & \multicolumn{2}{|c|}{$\begin{array}{c}\text { Plant length } \\
(\mathrm{cm})\end{array}$} & \multicolumn{2}{|c|}{$\begin{array}{l}\text { No. of } \\
\text { leaves }\end{array}$} & \multicolumn{2}{|c|}{$\begin{array}{c}\text { Plant fresh weight } \\
\text { (g) }\end{array}$} & \multicolumn{2}{|c|}{$\begin{array}{c}\text { Plant dry matter } \\
\%\end{array}$} \\
\hline & & $\begin{array}{c}1^{\text {st }} \\
\text { season } \\
\end{array}$ & $\begin{array}{c}2^{\text {nd }} \\
\text { season }\end{array}$ & $\begin{array}{c}1^{\text {st }} \\
\text { season } \\
\end{array}$ & $\begin{array}{c}2^{\text {nd }} \\
\text { season } \\
\end{array}$ & $\begin{array}{c}1^{\text {st }} \\
\text { season } \\
\end{array}$ & $\begin{array}{c}2^{\text {nd }} \\
\text { season } \\
\end{array}$ & $\begin{array}{c}1^{\text {st }} \\
\text { season } \\
\end{array}$ & $\begin{array}{c}2^{\text {nd }} \\
\text { season } \\
\end{array}$ \\
\hline \multicolumn{10}{|c|}{ a) Effect of treatment } \\
\hline \multicolumn{2}{|c|}{ Without bio-fertilizer } & $26.54^{\mathrm{c}}$ & $28.21^{\mathrm{c}}$ & $22.08^{\mathrm{c}}$ & $22.42^{\mathrm{c}}$ & $775.75^{\mathrm{c}}$ & $871.28^{c}$ & $12.67^{\mathrm{c}}$ & $13.73^{\mathrm{c}}$ \\
\hline \multicolumn{2}{|c|}{ Azotobacter chroococcum } & $37.79^{\mathrm{a}}$ & $37.75^{\mathrm{a}}$ & $32.33^{\mathrm{a}}$ & $34.00^{\mathrm{a}}$ & $837.17^{\mathrm{a}}$ & $929.17^{\mathrm{a}}$ & $18.52^{\mathrm{a}}$ & $19.43^{\mathrm{a}}$ \\
\hline \multicolumn{2}{|c|}{ Azospirillum brasilense } & $32.42^{\mathrm{b}}$ & $34.08^{b}$ & $27.58^{\mathrm{b}}$ & $28.58^{\mathrm{b}}$ & $811.00^{\mathrm{b}}$ & $903.54^{b}$ & $16.45^{\mathrm{b}}$ & $16.79^{b}$ \\
\hline \multicolumn{10}{|c|}{ b) Effect of mineral and vermi-compost } \\
\hline \multicolumn{2}{|l|}{$100 \% \mathrm{M}$} & $27.44^{\mathrm{d}}$ & $27.83^{\mathrm{c}}$ & $19.78^{\mathrm{D}}$ & $22.89^{\mathrm{d}}$ & $738.11^{\mathrm{c}}$ & $831.22^{\mathrm{c}}$ & $13.67^{\mathrm{d}}$ & $14.43^{\mathrm{c}}$ \\
\hline \multicolumn{2}{|c|}{$50 \% \mathrm{M}+50 \% \mathrm{VC}$} & $29.67^{c}$ & $30.89^{\mathrm{b}}$ & $24.67^{\mathrm{C}}$ & $25.22^{\mathrm{c}}$ & $772.00^{\mathrm{b}}$ & $863.22^{b}$ & $14.72^{\mathrm{c}}$ & $15.14^{\mathrm{b}}$ \\
\hline \multicolumn{2}{|c|}{$25 \% \mathrm{M}+75 \% \mathrm{VC}$} & $35.39^{\mathrm{a}}$ & $37.00^{\mathrm{a}}$ & $31.00^{\mathrm{B}}$ & $31.22^{\mathrm{b}}$ & $859.22^{\mathrm{a}}$ & $956.70^{\mathrm{a}}$ & $17.30^{\mathrm{b}}$ & $18.40^{\mathrm{a}}$ \\
\hline \multicolumn{2}{|l|}{$100 \% \mathrm{VC}$} & $36.50^{\mathrm{a}}$ & $37.67^{\mathrm{a}}$ & $33.89^{\mathrm{A}}$ & $34.00^{\mathrm{a}}$ & $862.56^{\mathrm{a}}$ & $954.17^{\mathrm{a}}$ & $17.83^{\mathrm{a}}$ & $18.62^{\mathrm{a}}$ \\
\hline \multicolumn{10}{|c|}{ c) Interactions } \\
\hline \multirow{4}{*}{$\begin{array}{l}\text { Without bio- } \\
\text { fertilizer }\end{array}$} & $100 \% \mathrm{M}$ & $22.33^{j}$ & $23.00^{\mathrm{j}}$ & $16.00 \mathrm{f}$ & $17.67 \mathrm{~g}$ & $718.00^{j}$ & $810.33^{\mathrm{k}}$ & $10.27^{\mathrm{i}}$ & $11.33^{\mathrm{i}}$ \\
\hline & $50 \% \mathrm{M}+50 \% \mathrm{VC}$ & $24.33^{\mathrm{i}}$ & $25.67^{\mathrm{i}}$ & $20.33 \mathrm{e}$ & $21.33^{\mathrm{f}}$ & $749.67^{\mathrm{h}}$ & $838.33^{j}$ & $12.06^{\mathrm{h}}$ & $13.10^{\mathrm{h}}$ \\
\hline & $25 \% \mathrm{M}+75 \% \mathrm{VC}$ & $30.67^{f}$ & $33.50 \mathrm{ef}$ & $28.33 \mathrm{c}$ & $27.00^{\mathrm{d}}$ & $826.33^{c}$ & $936.43^{\mathrm{e}}$ & $15.10^{\mathrm{e}}$ & $16.23^{\mathrm{e}}$ \\
\hline & $100 \% \mathrm{VC}$ & $28.83^{\mathrm{gh}}$ & $30.67 \mathrm{~g}$ & $23.67 \mathrm{de}$ & $23.67^{\mathrm{ef}}$ & $809.00^{\mathrm{d}}$ & $900.00^{\mathrm{f}}$ & $13.23^{\mathrm{g}}$ & $14.23^{\mathrm{g}}$ \\
\hline \multirow{4}{*}{$\begin{array}{l}\text { Azotobacter } \\
\text { chroococcum }\end{array}$} & $100 \% \mathrm{M}$ & $32.00^{\mathrm{e}}$ & $31.83^{\mathrm{fg}}$ & $23.00 \mathrm{de}$ & $28.00 \mathrm{~d}$ & $759.33^{\mathrm{g}}$ & $851.33^{\mathrm{i}}$ & $16.60^{\mathrm{d}}$ & $17.73^{\mathrm{d}}$ \\
\hline & $50 \% \mathrm{M}+50 \% \mathrm{VC}$ & $34.67^{\mathrm{d}}$ & $35.00^{\mathrm{de}}$ & $28.00 \mathrm{c}$ & $28.33 \mathrm{~cd}$ & $793.67^{e}$ & $887.00^{\mathrm{g}}$ & $16.67^{\mathrm{d}}$ & $16.83^{\mathrm{e}}$ \\
\hline & $25 \% \mathrm{M}+75 \% \mathrm{VC}$ & $39.83^{b}$ & $41.17^{\mathrm{b}}$ & $35.67 \mathrm{~b}$ & $36.00 \mathrm{~b}$ & $894.33^{\mathrm{a}}$ & $984.00^{\mathrm{b}}$ & $19.06^{\mathrm{b}}$ & $20.20^{\mathrm{b}}$ \\
\hline & $100 \% \mathrm{VC}$ & $44.67^{\mathrm{a}}$ & $43.00^{\mathrm{a}}$ & $42.67 \mathrm{a}$ & $43.67 \mathrm{a}$ & $909.33^{\mathrm{a}}$ & $994.33^{\mathrm{a}}$ & $21.73^{\mathrm{a}}$ & $22.93^{\mathrm{a}}$ \\
\hline \multirow{4}{*}{$\begin{array}{l}\text { Azospirillum } \\
\text { brasilense }\end{array}$} & $100 \% \mathrm{M}$ & $28.00^{\mathrm{h}}$ & $28.67^{\mathrm{h}}$ & $20.33^{e}$ & $23.00^{\mathrm{f}}$ & $737.00^{\mathrm{i}}$ & $832.00^{j}$ & $14.13^{\mathrm{f}}$ & $14.23^{\mathrm{g}}$ \\
\hline & $50 \% \mathrm{M}+50 \% \mathrm{VC}$ & $30.00^{\mathrm{fg}}$ & $32.00^{\mathrm{fg}}$ & $25.67 \mathrm{~cd}$ & $26.00 \mathrm{de}$ & $772.67^{\mathrm{f}}$ & $864.33^{\mathrm{h}}$ & $15.41^{\mathrm{e}}$ & $15.49^{f}$ \\
\hline & $25 \% \mathrm{M}+75 \% \mathrm{VC}$ & $35.67^{\mathrm{cd}}$ & $36.33^{\mathrm{d}}$ & $29.00 \mathrm{c}$ & $30.67 \mathrm{c}$ & $857.00^{\mathrm{c}}$ & $949.67^{d}$ & $17.73^{\mathrm{c}}$ & $18.76^{\mathrm{c}}$ \\
\hline & $100 \% \mathrm{VC}$ & $36.00^{\mathrm{c}}$ & $39.33^{\mathrm{c}}$ & $35.33 b$ & $34.67 b$ & $877.33^{b}$ & $968.17^{\mathrm{c}}$ & $18.53^{\mathrm{b}}$ & $18.70^{\mathrm{c}}$ \\
\hline
\end{tabular}

Values followed by the same letter (s) are not significantly different at 5\%. M, Mineral; VC, Vermicompost.

The increase in plant vegetative parameters may be attributed to the increase of nutrients absorption due to the combined effect of vermin-compost and bio-fertilizers (Abou El-Magd, et al., 2009). The existence of these two forms of fertilizers in the soil enhance the soil ability to retain 
moisture and enhances nutrients availability in the soil solution and nutrients use efficiency (Sharma, 2000). Moreover, the role of vermicompost of enhancing the soil physical and chemical properties (Ali et al., 2017; Hammadi et al., 2014; Darzi et al., 2012).

The effect of vermicompost different doses on lettuce plant length, number of leaves, fresh weight, dry weight was reported by Frasetya et al., (2019), where he reported that $5 \mathrm{t} \mathrm{ha}^{-1}$ vermicompost was the best dose to support growth, efficiency and improves plant growth. Moreover, Alper Durak et al., (2017) reported the same results and attributed the effect of vermicompost by increasing soil humic acid content and consequently increases plant growth hormones and other beneficial symbiotic microorganisms. Besides, it helps availability of plant nutrients by improving soil structure and microorganism activity and also this way increases plant growth. Rakesh et al., (2015) reported the superiority of vermicompost enhancing plant physical and chemical characteristics and encouraging the use of organic and bio-fertilizers.

\subsection{Effect of different fertilizer sources on physical characteristics}

Concerning the physical properties of lettuce plants, data illustrated in table (4a) reveal that, there are significant differences due to the application of biofertilizer compared to the control treatment. Azotobacter chroococcum treatment was superior in all measured values for the two seasons. It significantly increased head length, and width contributing to a net significant increase in the head weight where the highest significant values were obtained compared to the case of no biofertilizer is added. Moreover, Azospirillum brasilense come in the second order enhancing all physical parameter of lettuce plants. Plant head length ranged between $14.25 \mathrm{~cm}$ to $17.15 \mathrm{~cm}$ and $13.08 \mathrm{~cm}$ to $18.25 \mathrm{~cm}$ in both seasons with lowest values recorded in case of the control treatment.

The effect of the application of vermi-compost and mineral fertilizer mixture is illustrated in table (4b). Data indicate that the superiority of $100 \%$ vermicompost of the recommended fertilizer unit where it significantly enhanced plant head length, width and weight compared to the application of mineral fertilizer alone. The highest values of head length, width and weight were obtained in case of the application of vermicompost $100 \%$ of the recommended fertilizer unit followed by the application of $25 \%$ mineral $+75 \%$ vermicompost of the recommended fertilizer unit with no significant differences in the two successive seasons. The application of $50 \%$ mineral $+50 \%$ vermicompost of the recommended fertilizer unit come in the second order with a significant difference compared with the control treatment (100\% mineral nitrogen of the recommended fertilizer unit).

The interactions between bio, mineral and vermicompost application is illustrated in table (4c). Data show that there are significant differences among all treatments with highest achieved values in case of $100 \%$ vermicompost of the recommended fertilizer unit combined with Azotobacter chroococcum. The highest head length, head width and head weight were achieved in case of application of 100\% vermicompost with Azotobacter chroococcum where it reached 21, $22 \mathrm{~cm}$ (head length), $19,19 \mathrm{~cm}$ (head width) and $824.33,831.33 \mathrm{~g} /$ plant (head weight) compared to $12.67 \mathrm{~cm}$ and $11 \mathrm{~cm}, 8.17,8.17 \mathrm{~cm}$ (head width) and $564.33,572.00 \mathrm{~g} / \mathrm{plant}$ (head weight) in case of the application of mineral fertilizer at the rate of $100 \%$ of the recommended dose without vermicompost or biofertilizer in the first and second seasons respectively.

The increasing lettuce yield and physical properties by Azotobacter chroococcum application is confirmed in many researches such as the work done by Masarirambi et al., (2012) who attributed the superiority of Azotobacter chroococcum treatment to its promoting role and the ability to fix nitrogen and enhancing soil properties. Where Mariola et al., (2008) reported the promotive role of Azospirillium on plants by producing hormones such auxins, gibberellins and cytokinin which enhance and promote plant development and vigor.

All findings are in agreement with those were reported by Mahmoud and Gad, (2020) on beans at 3 ton/fed vermicompost. Abou El- Hassan et al., (2017), Sevinç et al., (2018) and Yassen et al. (2019) reported the increasing dose of vermi-compost increased lettuce growth, yield and quality. Abou ElHassan et al., (2017) reported the application of 5.04 ton/fed was the outperforming treatment in all studied parameters. 
Table 4: Effect of mineral nitrogen, vermi-compost and bio-fertilizer and their interaction on lettuce physical characteristics during 2018/2019 and 2019/2020 seasons.

\begin{tabular}{|c|c|c|c|c|c|c|c|}
\hline \multirow{2}{*}{\multicolumn{2}{|c|}{ Treatments }} & \multicolumn{2}{|c|}{ Head length (cm) } & \multicolumn{2}{|c|}{ Head width (cm) } & \multicolumn{2}{|c|}{ Head weight (g) } \\
\hline & & $\begin{array}{c}1^{\text {st }} \\
\text { season } \\
\end{array}$ & $\begin{array}{c}2^{\text {nd }} \\
\text { season }\end{array}$ & \multirow[t]{2}{*}{$\begin{array}{c}1^{\text {st }} \\
\text { season } \\
\end{array}$} & \multirow[t]{2}{*}{$\begin{array}{c}2^{\text {nd }} \\
\text { season }\end{array}$} & \multirow[t]{2}{*}{$\begin{array}{c}1^{\text {st }} \\
\text { season } \\
\end{array}$} & \multirow[t]{2}{*}{$\begin{array}{c}2^{\text {nd }} \\
\text { season } \\
\end{array}$} \\
\hline \multicolumn{4}{|c|}{ a) Effect of treatment } & & & & \\
\hline \multicolumn{2}{|c|}{ Without bio-fertilizer } & $14.25^{\mathrm{c}}$ & $13.08^{\mathrm{c}}$ & $11.14^{\mathrm{c}}$ & $10.79^{\mathrm{c}}$ & $632.53^{\mathrm{c}}$ & $642.25^{\mathrm{c}}$ \\
\hline \multicolumn{2}{|c|}{ Azotobacter chroococcum } & $17.15^{\mathrm{a}}$ & $18.25^{\mathrm{a}}$ & $15.92^{\mathrm{a}}$ & $15.33^{\mathrm{a}}$ & $768.21^{\mathrm{a}}$ & $772.17^{\mathrm{a}}$ \\
\hline \multicolumn{2}{|c|}{ Azospirillum brasilense } & $15.25^{\mathrm{b}}$ & $15.33^{\mathrm{b}}$ & $13.21^{\mathrm{b}}$ & $13.08^{\mathrm{b}}$ & $738.13^{\mathrm{b}}$ & $727.21^{\mathrm{b}}$ \\
\hline \multicolumn{8}{|c|}{ b) Effect of mineral and vermi-compost } \\
\hline \multicolumn{2}{|l|}{$100 \% \mathrm{M}$} & $12.98^{\mathrm{d}}$ & $12.89^{\mathrm{c}}$ & $10.44^{\mathrm{c}}$ & $10.17^{\mathrm{c}}$ & $630.89^{c}$ & $634.00^{\mathrm{c}}$ \\
\hline \multicolumn{2}{|l|}{$50 \% \mathrm{M}+50 \% \mathrm{VC}$} & $14.22^{\mathrm{c}}$ & $14.22^{\mathrm{b}}$ & $12.36^{\mathrm{b}}$ & $11.83^{\mathrm{b}}$ & $694.67^{\mathrm{b}}$ & $685.00^{\mathrm{b}}$ \\
\hline \multicolumn{2}{|l|}{$25 \% \mathrm{M}+75 \% \mathrm{VC}$} & $16.78^{b}$ & $17.33^{\mathrm{a}}$ & $15.17^{\mathrm{a}}$ & $14.78^{\mathrm{a}}$ & $762.42^{\mathrm{a}}$ & $767.61^{\mathrm{a}}$ \\
\hline \multicolumn{2}{|l|}{$100 \% \mathrm{VC}$} & $18.22^{\mathrm{a}}$ & $17.78^{\mathrm{a}}$ & $15.72^{\mathrm{a}}$ & $15.50^{\mathrm{a}}$ & $763.83^{a}$ & $768.89^{a}$ \\
\hline \multicolumn{8}{|c|}{ c) Interactions } \\
\hline \multirow{4}{*}{$\begin{array}{l}\text { Without bio- } \\
\text { fertilizer }\end{array}$} & $100 \% \mathrm{M}$ & $12.67^{g}$ & $11.00^{\mathrm{i}}$ & $8.17^{\mathrm{g}}$ & $8.17^{\mathrm{g}}$ & $564.33^{j}$ & $572.00^{\mathrm{k}}$ \\
\hline & $50 \% \mathrm{M}+50 \% \mathrm{VC}$ & $13.00^{\mathrm{fg}}$ & $12.67^{\mathrm{gh}}$ & $10.40^{\mathrm{f}}$ & $9.83^{\mathrm{f}}$ & $611.33^{\mathrm{i}}$ & $603.67^{\mathrm{j}}$ \\
\hline & $25 \% \mathrm{M}+75 \% \mathrm{VC}$ & $16.33^{\mathrm{c}}$ & $15.00^{\mathrm{de}}$ & $13.50^{\mathrm{d}}$ & $13.67^{\mathrm{cd}}$ & $690.43^{\mathrm{f}}$ & $710.33^{\mathrm{f}}$ \\
\hline & $100 \% \mathrm{VC}$ & $15.00^{\mathrm{de}}$ & $13.67^{\mathrm{fg}}$ & $12.50^{\mathrm{de}}$ & $11.50^{\mathrm{e}}$ & $664.00^{\mathrm{g}}$ & $683.00^{\mathrm{h}}$ \\
\hline \multirow{4}{*}{$\begin{array}{l}\text { Azotobacter } \\
\text { chroococcum }\end{array}$} & $100 \% \mathrm{M}$ & $13.93^{\text {ef }}$ & $15.33^{\mathrm{d}}$ & $13.00^{\mathrm{de}}$ & $12.33^{\mathrm{de}}$ & $681.33^{f}$ & $689.33^{\text {gh }}$ \\
\hline & $50 \% \mathrm{M}+50 \% \mathrm{VC}$ & $15.67^{\mathrm{cd}}$ & $16.00^{\mathrm{d}}$ & $14.67^{\mathrm{c}}$ & $14.00^{\mathrm{c}}$ & $758.33^{d}$ & $753.67^{\mathrm{e}}$ \\
\hline & $25 \% \mathrm{M}+75 \% \mathrm{VC}$ & $18.00^{\mathrm{b}}$ & $19.67^{\mathrm{b}}$ & $17.00^{\mathrm{b}}$ & $16.00^{\mathrm{b}}$ & $808.83^{b}$ & $814.33^{b}$ \\
\hline & $100 \% \mathrm{VC}$ & $21.00^{\mathrm{a}}$ & $22.00^{\mathrm{a}}$ & $19.00^{\mathrm{a}}$ & $19.00^{\mathrm{a}}$ & $824.33^{\mathrm{a}}$ & $831.33^{\mathrm{a}}$ \\
\hline \multirow{4}{*}{$\begin{array}{l}\text { Azospirillum } \\
\text { brasilense }\end{array}$} & $100 \% \mathrm{M}$ & $12.33^{\mathrm{g}}$ & $12.33^{\mathrm{h}}$ & $10.17^{\mathrm{f}}$ & $10.00^{\mathrm{f}}$ & $647.00^{\mathrm{h}}$ & $640.67^{i}$ \\
\hline & $50 \% \mathrm{M}+50 \% \mathrm{VC}$ & $14.00^{\text {ef }}$ & $14.00^{\mathrm{ef}}$ & $12.00^{\mathrm{e}}$ & $11.67^{\mathrm{e}}$ & $714.33^{\mathrm{e}}$ & $697.67^{\mathrm{g}}$ \\
\hline & $25 \% \mathrm{M}+75 \% \mathrm{VC}$ & $16.00^{\mathrm{cd}}$ & $17.33^{\mathrm{c}}$ & $17.33^{\mathrm{c}}$ & $14.67^{\mathrm{bc}}$ & $788.00^{\mathrm{c}}$ & $778.17^{\mathrm{d}}$ \\
\hline & $100 \% \mathrm{VC}$ & $18.67^{b}$ & $17.67^{\mathrm{c}}$ & $15.67^{\mathrm{c}}$ & $16.00^{\mathrm{b}}$ & $803.17^{\mathrm{b}}$ & $792.33^{c}$ \\
\hline
\end{tabular}

Values followed by the same letter (s) are not significantly different at 5\%. M, Mineral; VC, Vermicompost.

Figure (1) represents the total yield per fadden where the lowest yield per fadden was 18.1 and 20.4 (ton/fed) as a result of $100 \%$ mineral of the recommended fertilizer unit with no biofertilizer and no vermicompost addition for the two successive seasons respectively. The highest value of yield recorded was 22.9 and 25.1 ton/fed in response to the application of Azotobacter chroococcum combined with $100 \%$ vermicompost of the recommended fertilizer unit for the two seasons respectively.

\subsection{Effect of different fertilizer sources on nutritional value of lettuce plant}

Nitrates, vitamin $\mathrm{C}$ are considered indicators for lettuces quality, where nitrate is responsible for the taste of the lettuce leaves and vitamin $\mathrm{C}$ are necessary for healthy bodies. Vitamin $\mathrm{C}$ increases human body resistance to viruses and bacterial infections. Data presented in table (5a) emphasizes the role of biofertilizers in enhancing lettuce quality. Data indicate that, the without bio-fertilizer treatment exhibited the lowest significant values of most of the aforementioned parameters especially total protein (\%), vitamin C (mg/100 FW) and total carbohydrates (\%), compared with other biofertilizer treatments. in the same context, the without bio-fertilizer treatment possess the highest nitrate content value where it recorded 343.06 and $379.08 \mathrm{mg} / \mathrm{kg}$ in the first and the second seasons respectively. The marvelous results have been achieved by Azotobacter chroococcum, which produced highest significant total protein (\%), vitamin $\mathrm{C}(\mathrm{mg} / 100 \mathrm{FW})$ and total carbohydrates (\%). This treatment, increased vitamin $\mathrm{C}$ by1.17 and 1.08 times than the corresponding control (without bio-fertilizer) respectively, in the first and second season. However, the Azospirillum brasilense increased vitamin C by only about 1.07 and 1.01 times than those of without bio-fertilizer in the two seasons, respectively.

Table (5b) show the response of lettuce nutritional parameters to the application of vermicompost and mineral fertilizer mixtures. Data indicates that the effect of $100 \%$ vermicompost of the 
recommended fertilizer unit was the highest values in total protein $(19.55,19.57 \%)$, vitamin $\mathrm{C}(28.42$, $28.39 \mathrm{mg} / 100 \mathrm{FW})$ and carbohydrates $(28.38,29.44 \%)$ in the two successive seasons respectively. While it was the lowest in nitrate content $(242.87,279.62 \mathrm{mg} / \mathrm{kg})$. This confirms the superiority of the application of vermicompost enhancing all nutritional parameters of lettuce plants compared to the mineral fertilizer. Data also indicates that all treatments are significantly different compared to each other with the lowest significant nutritional values in case of the application of $100 \%$ mineral fertilizers of the recommended dose in clay soil.

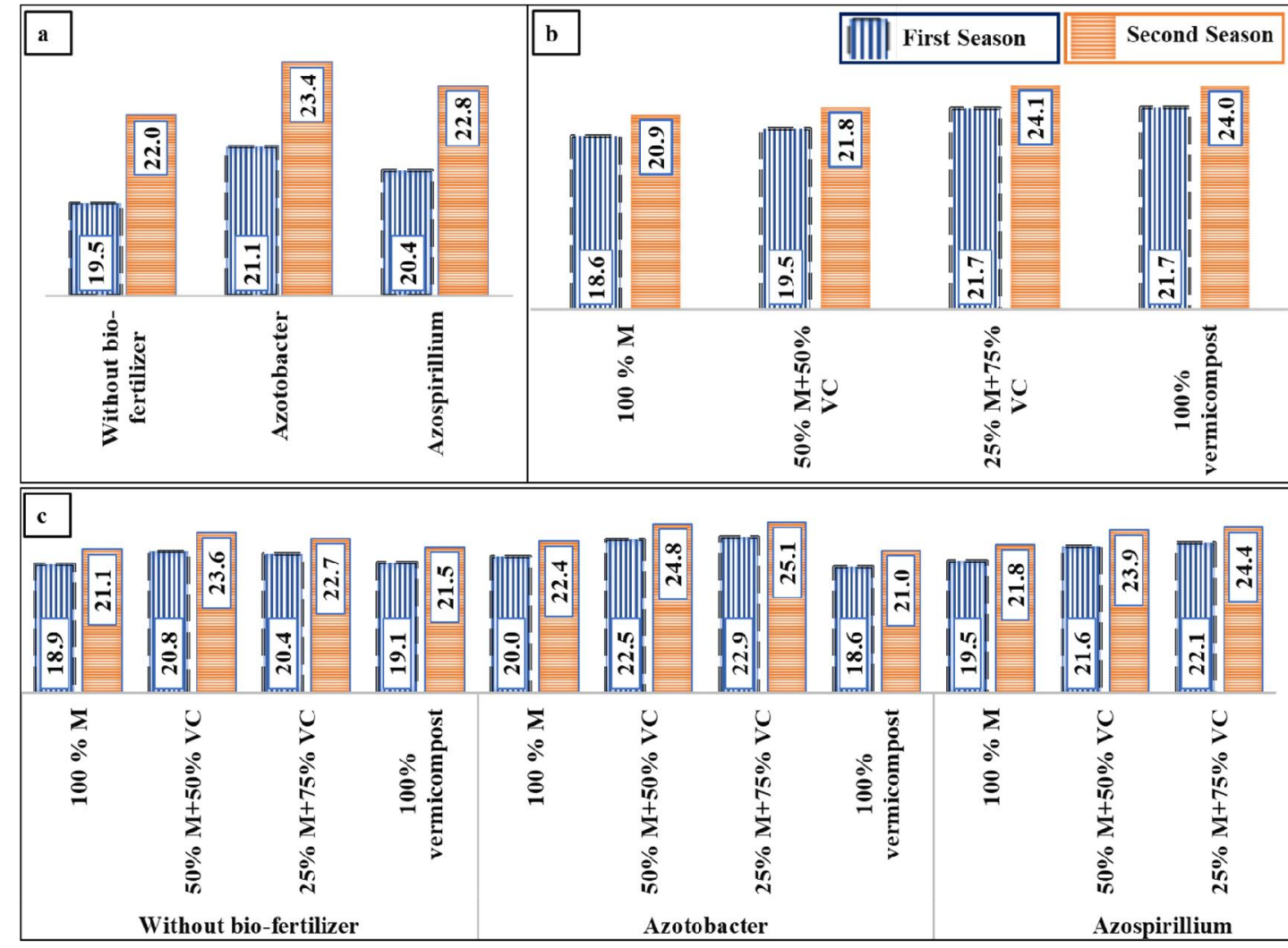

Fig. 1: Response of lettuce total yield (ton/fed) to the application of different fertilizer a) effect of biofertilizer, b) effect of vermicompost and mineral fertilizer mixtures, c) interaction between both biofertilizers + vermicompost and mineral fertilizer mixture during 2018/2019 and 2019/2020 seasons. M, Mineral; VC, Vermicompost.

Table (5c) presents the response of lettuce to the interaction of the applications of biofertilizer, vermicompost and mineral fertilizer at different levels and concentrations. Data emphasizes the promoting role of both biofertilizers and vermicompost. Where the highest significant increase in the nutritional values were obtained in case of the application of Azotobacter $+100 \%$ vermicompost mixture. Nitrate concentration in leaves as affected by interactions between bio-fertilizers, mineral and vermicompost application are presented in figure (2).

Biofertilizers and vermicompost combinations significantly increased total carbohydrates, total protein and vitamin $C$ in lettuce plants opposite to nitrate content which was significantly decreased in response to the application of biofertilizers and vermicompost mixtures. This was confirmed by Hanafy et al. (1997) who reported the role of biofertilizers to lower nitrate concentration decreased with vermicompost and biofertilizer application in jew's mallow and radish plants while total carbohydrates, total protein were significantly increased. Blom-Zandstra et al., (1988) indicated that accumulation of $\mathrm{NO}_{3}$ was inversely correlated to sugars and organic acids accumulation in lettuce plants. Moreover, Imsande and Touraine (1994) found that increasing of certain amino acids concentration in the phloem sap reduce nitrate uptake. Many authors confirmed the role of bacteria that is found in the biofertilizers to fix nitrogen, dissolving phosphorus, produce different organic acids and plant growth promoters 
(auxins, gibberellins and cytokinins), which consequently reduce soil $\mathrm{pH}$ (Chi et al., 2010; Thamer et al., 2011; Sahoo et al., 2013).

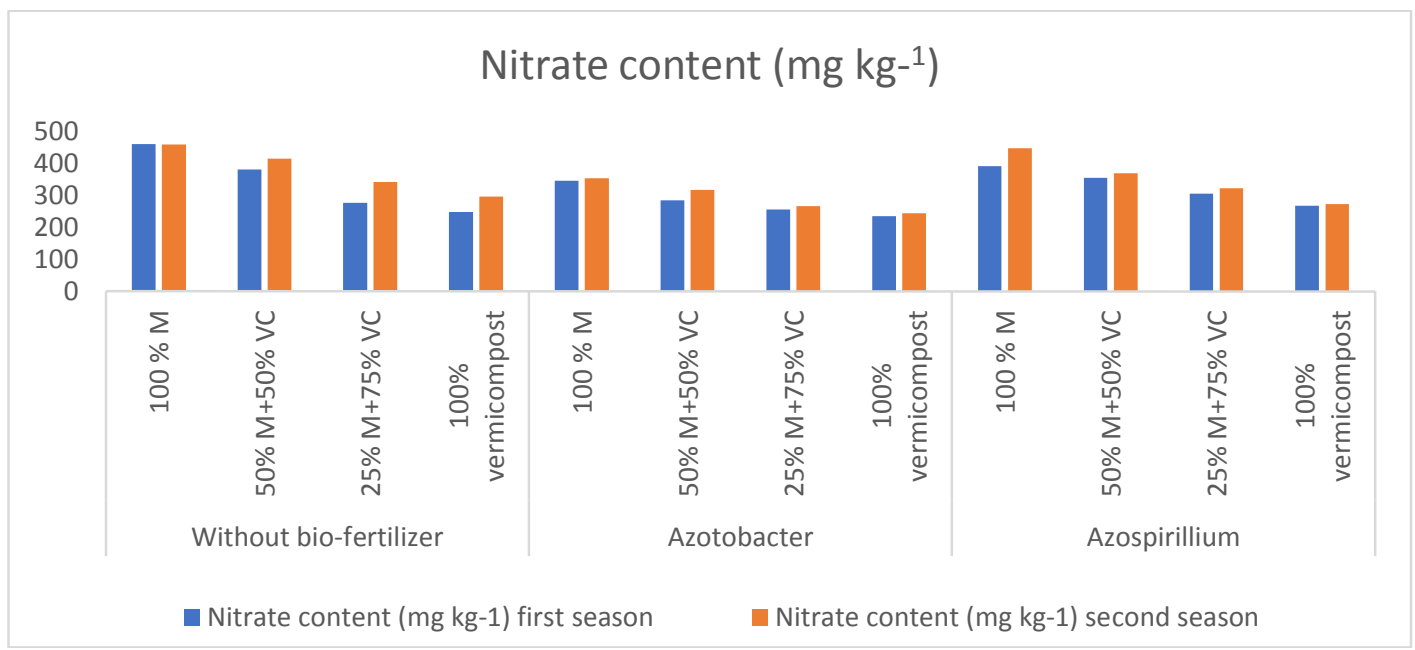

Fig 2: Nitrate concentration in leaves in response to different fertilizers application.

Table 5: Effect of mineral nitrogen, vermicompost and biofertilizer and their interaction on lettuce nutritional value during 2018/2019 and 2019/2020 seasons.

\begin{tabular}{|c|c|c|c|c|c|c|c|c|c|}
\hline \multirow{2}{*}{\multicolumn{2}{|c|}{ Treatments }} & \multicolumn{2}{|c|}{$\begin{array}{l}\text { Nitrate content } \\
\left(\mathrm{mg} \mathrm{kg}^{-1}\right)\end{array}$} & \multicolumn{2}{|c|}{$\begin{array}{c}\text { Total protein } \\
(\%)\end{array}$} & \multicolumn{2}{|c|}{$\begin{array}{c}\text { Vitamin C } \\
(\mathrm{mg} / 100 \text { FW) }\end{array}$} & \multicolumn{2}{|c|}{$\begin{array}{c}\text { Carbohydrates } \\
(\%)\end{array}$} \\
\hline & & $\begin{array}{c}1^{\text {st }} \\
\text { season }\end{array}$ & $\begin{array}{c}2^{\text {nd }} \\
\text { season }\end{array}$ & $\begin{array}{c}1^{\text {st }} \\
\text { season }\end{array}$ & $\begin{array}{c}2^{\text {nd }} \\
\text { season }\end{array}$ & $\begin{array}{c}1^{\text {st }} \\
\text { season }\end{array}$ & $\begin{array}{c}2^{\text {nd }} \\
\text { season }\end{array}$ & $\begin{array}{c}1^{\text {st }} \\
\text { season }\end{array}$ & $\begin{array}{c}2^{\text {nd }} \\
\text { season }\end{array}$ \\
\hline \multicolumn{10}{|c|}{ a) Effect of treatment } \\
\hline \multicolumn{2}{|c|}{ Without bio-fertilizer } & $343.06^{\mathrm{a}}$ & $379.08^{\mathrm{a}}$ & $14.36^{\mathrm{c}}$ & $13.67^{\mathrm{c}}$ & $23.38^{\mathrm{c}}$ & $24.518^{b}$ & $21.90^{\mathrm{c}}$ & $22.31^{\mathrm{c}}$ \\
\hline \multicolumn{2}{|c|}{ Azotobacter chroococcum } & $281.45^{\mathrm{c}}$ & $295.82^{\mathrm{c}}$ & $20.10^{\mathrm{a}}$ & $20.81^{\mathrm{a}}$ & $27.42^{\mathrm{a}}$ & $26.53^{\mathrm{a}}$ & $29.53^{b}$ & $30.57^{\mathrm{a}}$ \\
\hline \multicolumn{2}{|c|}{ Azospirillum brasilense } & $330.63^{b}$ & $353.84^{\mathrm{b}}$ & $17.98^{\mathrm{b}}$ & $18.82^{\mathrm{b}}$ & $25.81^{\mathrm{b}}$ & $24.97^{\mathrm{b}}$ & $26.45^{\mathrm{a}}$ & $27.60^{\mathrm{b}}$ \\
\hline \multicolumn{10}{|c|}{ b) Effect of mineral and vermicompost } \\
\hline \multicolumn{2}{|l|}{$100 \% \mathrm{M}$} & $375.62^{\mathrm{a}}$ & $421.41^{\mathrm{a}}$ & $15.03^{\mathrm{c}}$ & $15.44^{\mathrm{c}}$ & $22.15^{\mathrm{d}}$ & $22.20^{\mathrm{d}}$ & $23.06^{\mathrm{c}}$ & $24.55^{\mathrm{c}}$ \\
\hline \multicolumn{2}{|c|}{$50 \% \mathrm{M}+50 \% \mathrm{VC}$} & $325.02^{\mathrm{b}}$ & $383.60^{\mathrm{b}}$ & $16.22^{\mathrm{b}}$ & $16.76^{\mathrm{b}}$ & $24.65^{\mathrm{c}}$ & $24.36^{\mathrm{c}}$ & $24.34^{\mathrm{b}}$ & $24.86^{\mathrm{c}}$ \\
\hline \multicolumn{2}{|c|}{$25 \% \mathrm{M}+75 \% \mathrm{VC}$} & $280.51^{\mathrm{c}}$ & $333.30^{\mathrm{c}}$ & $19.13^{\mathrm{a}}$ & $19.29^{\mathrm{a}}$ & $26.91^{\mathrm{b}}$ & $26.41^{\mathrm{b}}$ & $28.07^{\mathrm{a}}$ & $28.47^{\mathrm{b}}$ \\
\hline \multicolumn{2}{|l|}{$100 \% \mathrm{VC}$} & $242.87^{\mathrm{d}}$ & $279.62^{\mathrm{d}}$ & $19.55^{\mathrm{a}}$ & $19.57^{\mathrm{a}}$ & $28.42^{\mathrm{a}}$ & $28.39^{\mathrm{a}}$ & $28.38^{\mathrm{a}}$ & $29.44^{\mathrm{a}}$ \\
\hline \multicolumn{10}{|c|}{ c) Interactions } \\
\hline \multirow{4}{*}{$\begin{array}{l}\text { Without bio- } \\
\text { fertilizer }\end{array}$} & $100 \% \mathrm{M}$ & $462.75^{\mathrm{a}}$ & $460.09^{\mathrm{a}}$ & $12.13^{\mathrm{h}}$ & $11.44^{\mathrm{i}}$ & $20.00^{\mathrm{h}}$ & $21.74^{\mathrm{h}}$ & $18.30^{\mathrm{g}}$ & $19.47^{\mathrm{g}}$ \\
\hline & $50 \% \mathrm{M}+50 \% \mathrm{VC}$ & $382.65^{\mathrm{b}}$ & $415.63^{b}$ & $13.23^{\mathrm{g}}$ & $13.19^{\mathrm{h}}$ & $22.07^{\mathrm{g}}$ & $23.33^{\mathrm{fg}}$ & $21.53^{\mathrm{f}}$ & $22.16^{\mathrm{f}}$ \\
\hline & $25 \% \mathrm{M}+75 \% \mathrm{VC}$ & $277.83^{\mathrm{ef}}$ & $343.5^{\mathrm{e}}$ & $16.77^{\mathrm{e}}$ & $15.96^{\mathrm{f}}$ & $26.93^{\mathrm{c}}$ & $28.07^{\mathrm{bc}}$ & $25.03^{\text {de }}$ & $24.77^{\mathrm{e}}$ \\
\hline & $100 \% \mathrm{VC}$ & $249.03^{\mathrm{hi}}$ & $297.13^{\mathrm{g}}$ & $15.31^{\mathrm{f}}$ & $14.08^{\mathrm{g}}$ & $24.50^{\mathrm{e}}$ & $24.93^{\mathrm{e}}$ & $22.74^{\mathrm{ef}}$ & $22.87^{\mathrm{f}}$ \\
\hline \multirow{4}{*}{$\begin{array}{l}\text { Azotobacter } \\
\text { chroococcum }\end{array}$} & $100 \% \mathrm{M}$ & $347.50^{c}$ & $354.53^{\mathrm{c}}$ & $17.50^{\mathrm{e}}$ & $18.50^{\mathrm{d}}$ & $23.44^{\mathrm{f}}$ & $22.57^{\mathrm{gh}}$ & $27.28^{\mathrm{cd}}$ & $29.65^{c}$ \\
\hline & $50 \% \mathrm{M}+50 \% \mathrm{VC}$ & $284.97^{\mathrm{e}}$ & $317.47^{\mathrm{d}}$ & $18.75^{\mathrm{d}}$ & $19.50^{\mathrm{c}}$ & $27.42^{\mathrm{c}}$ & $25.58^{\mathrm{de}}$ & $26.38^{\mathrm{cd}}$ & $26.50^{\mathrm{d}}$ \\
\hline & $25 \% \mathrm{M}+75 \% \mathrm{VC}$ & $257.27^{\text {gh }}$ & $266.80^{\mathrm{fg}}$ & $21.25^{\mathrm{b}}$ & $22.00^{\mathrm{b}}$ & $28.13^{\mathrm{b}}$ & $26.88^{\mathrm{cd}}$ & $30.70^{\mathrm{b}}$ & $31.44^{\mathrm{b}}$ \\
\hline & $100 \% \mathrm{VC}$ & $236.07^{\mathrm{i}}$ & $244.50^{\mathrm{hi}}$ & $22.92^{\mathrm{a}}$ & $23.25^{\mathrm{a}}$ & $30.67^{\mathrm{a}}$ & $31.08^{\mathrm{a}}$ & $33.78^{\mathrm{a}}$ & $34.71^{\mathrm{a}}$ \\
\hline \multirow{4}{*}{$\begin{array}{c}\text { Azospirillum } \\
\text { brasilense }\end{array}$} & $100 \% \mathrm{M}$ & $392.17^{\mathrm{c}}$ & $449.20^{\mathrm{a}}$ & $15.48^{\mathrm{f}}$ & $16.38^{\mathrm{f}}$ & $23.02^{\mathrm{f}}$ & $22.29^{\mathrm{gh}}$ & $23.60^{\mathrm{ef}}$ & $24.54^{\mathrm{e}}$ \\
\hline & $50 \% \mathrm{M}+50 \% \mathrm{VC}$ & $354.93^{\mathrm{d}}$ & $369.93^{\mathrm{d}}$ & $16.67^{\mathrm{e}}$ & $17.60^{\mathrm{e}}$ & $24.45^{\mathrm{e}}$ & $24.15^{\mathrm{ef}}$ & $25.10^{\text {de }}$ & $25.93^{\mathrm{d}}$ \\
\hline & $25 \% \mathrm{M}+75 \% \mathrm{VC}$ & $306.73^{\mathrm{g}}$ & $323.23^{f}$ & $19.38^{d}$ & $19.92^{\mathrm{c}}$ & $25.67^{d}$ & $24.29^{\mathrm{ef}}$ & $28.48^{\mathrm{bc}}$ & $29.20^{\mathrm{c}}$ \\
\hline & $100 \% \mathrm{VC}$ & $268.70^{\mathrm{hi}}$ & $273.03^{\mathrm{h}}$ & $20.42^{\mathrm{c}}$ & $21.38^{\mathrm{b}}$ & $30.10^{\mathrm{a}}$ & $29.17^{\mathrm{b}}$ & $28.63^{\mathrm{bc}}$ & $30.74^{\mathrm{b}}$ \\
\hline
\end{tabular}

Values followed by the same letter (s) are not significantly different at 5\%. M, Mineral; VC, Vermicompost. 


\subsection{Effect of different fertilizer sources on minerals content}

It is well known that following up $\mathrm{N}, \mathrm{P}, \mathrm{K}$ and $\mathrm{Ca}$ in the vegetative growth of lettuce plant, is great importance and correlate with the other parameters. Data presented in table (6) show the variations of these elements induced by the application of different fertilizers mixtures and concentrations. The main point that has captured our attention is that, all parameters responded significantly to the investigated treatments in comparison with the corresponding control.

Data in table (6a) illustrate that, all biofertilizer treatments resulted in significant high levels of minerals content compared with without bio-fertilizer treatments. Nitrogen contents in lettuce leaves ranged between 2.3 and $3.22 \%$ in the first season and from 2.19 to $3.33 \%$ in the second season. While phosphors content ranged between 0.51 and 0.59 in the first season and from 0.53 to 0.60 in the second season. On the other hand, $\mathrm{K}$ and $\mathrm{Ca}$ contents ranged between $1.4-1.93$ and $1.51-1.87$ in the first season and $1.48-1.93$ and $1.42-1.74$ in the second season respectively.

Table 6: Effect of mineral nitrogen, vermicompost and biofertilizer and their interaction on lettuce minerals content during 2018/2019 and 2019/2020 seasons.

\begin{tabular}{|c|c|c|c|c|c|c|c|c|c|}
\hline \multirow{2}{*}{\multicolumn{2}{|c|}{ Treatments }} & \multicolumn{2}{|c|}{$\mathbf{N}(\%)$} & \multicolumn{2}{|c|}{$\mathbf{P}(\%)$} & \multicolumn{2}{|c|}{ K (\%) } & \multicolumn{2}{|c|}{$\mathrm{Ca}(\%)$} \\
\hline & & \multirow[t]{2}{*}{$\begin{array}{c}1^{\text {st }} \\
\text { season } \\
\end{array}$} & $\begin{array}{c}2^{\text {nd }} \\
\text { season } \\
\end{array}$ & $\begin{array}{c}1^{\text {st }} \\
\text { season }\end{array}$ & \multirow[t]{2}{*}{$\begin{array}{c}2^{\text {nd }} \\
\text { season }\end{array}$} & \multirow[t]{2}{*}{$\begin{array}{c}1^{\text {st }} \\
\text { season }\end{array}$} & \multirow[t]{2}{*}{$\begin{array}{c}2^{\text {nd }} \\
\text { season } \\
\end{array}$} & \multirow[t]{2}{*}{$\begin{array}{c}1^{\text {st }} \\
\text { season } \\
\end{array}$} & \multirow[t]{2}{*}{$\begin{array}{c}2^{\text {nd }} \\
\text { season } \\
\end{array}$} \\
\hline & & & a) Effec & f treatm & & & & & \\
\hline \multicolumn{2}{|c|}{ Without bio-fertilizer } & $2.30^{\mathrm{c}}$ & $2.19^{\mathrm{c}}$ & $0.51^{\mathrm{c}}$ & $0.53^{\mathrm{c}}$ & $1.40^{\mathrm{c}}$ & $1.48^{\mathrm{c}}$ & $1.51^{\mathrm{c}}$ & $1.42^{\mathrm{c}}$ \\
\hline \multicolumn{2}{|c|}{ Azotobacter chroococcum } & $3.22^{\mathrm{a}}$ & $3.33^{\mathrm{a}}$ & $0.59^{\mathrm{a}}$ & $0.60^{\mathrm{a}}$ & $1.93^{\mathrm{a}}$ & $1.93^{\mathrm{a}}$ & $1.87^{\mathrm{a}}$ & $1.74^{\mathrm{a}}$ \\
\hline \multicolumn{2}{|c|}{ Azospirillum brasilense } & $2.88^{\mathrm{b}}$ & $3.01^{\mathrm{b}}$ & $0.56^{\mathrm{b}}$ & $0.57^{b}$ & $1.72^{\mathrm{b}}$ & $1.69^{\mathrm{b}}$ & $1.67^{b}$ & $1.51^{\mathrm{b}}$ \\
\hline \multicolumn{10}{|c|}{ b) Effect of mineral and vermicompost } \\
\hline \multicolumn{2}{|l|}{$100 \% \mathrm{M}$} & $2.41^{\mathrm{c}}$ & $2.47^{\mathrm{c}}$ & $0.46^{\mathrm{d}}$ & $0.53^{\mathrm{c}}$ & $1.44^{\mathrm{d}}$ & $1.47^{\mathrm{d}}$ & $1.50^{\mathrm{d}}$ & $1.39^{\mathrm{c}}$ \\
\hline \multicolumn{2}{|l|}{$50 \% \mathrm{M}+50 \% \mathrm{VC}$} & $2.59^{\mathrm{b}}$ & $2.68^{\mathrm{b}}$ & $0.51^{\mathrm{c}}$ & $0.55^{\mathrm{b}}$ & $1.55^{\mathrm{c}}$ & $1.58^{\mathrm{c}}$ & $1.60^{\mathrm{c}}$ & $1.41^{\mathrm{c}}$ \\
\hline \multicolumn{2}{|l|}{$25 \% \mathrm{M}+75 \% \mathrm{VC}$} & $3.06^{\mathrm{a}}$ & $3.09^{\mathrm{a}}$ & $0.59^{\mathrm{b}}$ & $0.59^{\mathrm{a}}$ & $1.78^{\mathrm{b}}$ & $1.82^{\mathrm{b}}$ & $1.78^{\mathrm{b}}$ & $1.68^{\mathrm{b}}$ \\
\hline \multicolumn{2}{|l|}{$100 \% \mathrm{VC}$} & $3.13^{\mathrm{a}}$ & $3.13^{\mathrm{a}}$ & $0.64^{\mathrm{a}}$ & $0.60^{\mathrm{a}}$ & $1.96^{\mathrm{a}}$ & $1.93^{\mathrm{a}}$ & $1.85^{\mathrm{a}}$ & $1.75^{\mathrm{a}}$ \\
\hline \multicolumn{10}{|c|}{ c) Interactions } \\
\hline \multirow{4}{*}{$\begin{array}{l}\text { Without } \\
\text { fertilizer }\end{array}$} & $100 \% \mathrm{M}$ & $1.94^{\mathrm{h}}$ & $1.83^{\mathrm{j}}$ & $0.42^{\mathrm{g}}$ & $0.49^{g}$ & $1.20^{\mathrm{g}}$ & $1.27^{\mathrm{g}}$ & $1.33^{\mathrm{h}}$ & $1.28^{\mathrm{i}}$ \\
\hline & $50 \% \mathrm{M}+50 \% \mathrm{VC}$ & $2.12^{\mathrm{g}}$ & $2.11^{\mathrm{i}}$ & $0.46^{\mathrm{f}}$ & $0.52^{f}$ & $1.32^{\mathrm{g}}$ & $1.43^{\mathrm{fg}}$ & $1.46^{\mathrm{g}}$ & $1.32^{\mathrm{h}}$ \\
\hline & $25 \% \mathrm{M}+75 \% \mathrm{VC}$ & $2.68^{\mathrm{e}}$ & $2.55^{\mathrm{g}}$ & $0.61^{\mathrm{c}}$ & $0.56^{\mathrm{de}}$ & $1.61^{\mathrm{de}}$ & $1.67^{\mathrm{de}}$ & $1.65^{\mathrm{ef}}$ & $1.58^{\mathrm{e}}$ \\
\hline & $100 \% \mathrm{VC}$ & $2.45^{\mathrm{f}}$ & $2.25^{\mathrm{h}}$ & $0.53^{\mathrm{e}}$ & $0.54^{\mathrm{ef}}$ & $1.47^{\mathrm{f}}$ & $1.54^{\mathrm{ef}}$ & $1.60^{\mathrm{f}}$ & $1.50^{\mathrm{f}}$ \\
\hline \multirow{4}{*}{$\begin{array}{l}\text { Azotobacter } \\
\text { chroococcum }\end{array}$} & $100 \% \mathrm{M}$ & $2.80^{\mathrm{e}}$ & $2.96^{\mathrm{e}}$ & $0.48^{\mathrm{f}}$ & $0.58^{\mathrm{cd}}$ & $1.67^{\text {cde }}$ & $1.71^{\text {cde }}$ & $1.71^{\mathrm{de}}$ & $1.60^{\mathrm{e}}$ \\
\hline & $50 \% \mathrm{M}+50 \% \mathrm{VC}$ & $3.00^{\mathrm{d}}$ & $3.12^{\mathrm{d}}$ & $0.55^{\mathrm{de}}$ & $0.57^{\mathrm{cd}}$ & $1.74^{\mathrm{cd}}$ & $1.68^{\mathrm{de}}$ & $1.74^{\text {cde }}$ & $1.50^{\mathrm{f}}$ \\
\hline & $25 \% \mathrm{M}+75 \% \mathrm{VC}$ & $3.40^{\mathrm{b}}$ & $3.52^{\mathrm{b}}$ & $0.60^{\mathrm{c}}$ & $0.62^{b}$ & $1.93^{\mathrm{b}}$ & $1.96^{\mathrm{b}}$ & $1.90^{\mathrm{b}}$ & $1.81^{\mathrm{b}}$ \\
\hline & $100 \% \mathrm{VC}$ & $3.67^{\mathrm{a}}$ & $3.72^{\mathrm{a}}$ & $0.72^{\mathrm{a}}$ & $0.65^{\mathrm{a}}$ & $2.38^{\mathrm{a}}$ & $2.36^{\mathrm{a}}$ & $2.13^{\mathrm{a}}$ & $2.05^{\mathrm{a}}$ \\
\hline \multirow{4}{*}{$\begin{array}{l}\text { Azospirillum } \\
\text { brasilense }\end{array}$} & $100 \% \mathrm{M}$ & $2.47^{\mathrm{f}}$ & $2.62^{\mathrm{g}}$ & $0.47^{\mathrm{f}}$ & $0.53^{\text {ef }}$ & $1.47^{\mathrm{f}}$ & $1.43^{\mathrm{fg}}$ & $1.47^{g}$ & $1.30^{\mathrm{hi}}$ \\
\hline & $50 \% \mathrm{M}+\mathbf{5 0} \% \mathrm{VC}$ & $2.67^{\mathrm{e}}$ & $2.82^{\mathrm{f}}$ & $0.53^{\mathrm{e}}$ & $0.56^{\mathrm{de}}$ & $1.58^{\mathrm{ef}}$ & $1.62^{\mathrm{e}}$ & $1.59^{\mathrm{f}}$ & $1.40^{\mathrm{g}}$ \\
\hline & $25 \% \mathrm{M}+75 \% \mathrm{VC}$ & $3.10^{\mathrm{d}}$ & $3.19^{\mathrm{d}}$ & $0.57^{d}$ & $0.60^{\mathrm{bc}}$ & $1.79^{c}$ & $1.82^{\mathrm{bcd}}$ & $1.80^{\mathrm{cd}}$ & $1.63^{\mathrm{d}}$ \\
\hline & $100 \% \mathrm{VC}$ & $3.27^{\mathrm{c}}$ & $3.42^{\mathrm{c}}$ & $0.67^{\mathrm{b}}$ & $0.60^{\mathrm{bc}}$ & $2.02^{\mathrm{b}}$ & $1.88^{\mathrm{bc}}$ & $1.82^{\mathrm{bc}}$ & $1.71^{\mathrm{c}}$ \\
\hline
\end{tabular}

Values followed by the same letter (s) are not significantly different at 5\%. M, Mineral; VC, Vermicompost.

Table (6b) present the effect of the application of vermicompost in combination with mineral fertilizer at different concentrations and rates. The application of $100 \%$ vermicompost of the recommended fertilizer unit led to the highest significant values of $\mathrm{N}, \mathrm{P}, \mathrm{K}$, and $\mathrm{Ca}$. this was followed by the application of $75 \%$ vermicompost $+25 \%$ of mineral fertilizer of the recommended fertilizer unit with a significant difference between the two treatments except in case of $\mathrm{N}$ content. it is noticeable that mineral fertilizer at the recommended fertilizer unit led to the lowest significant values of minerals content of lettuce plants.

Data reported in table (6c) indicated that increased mineral content in lettuce plant and the highest values of mineral percentages were produced by inoculated plants with Azotobacter combined with 
application of $100 \%$ vermicompost of the recommended fertilizer unit. Whereas, the lowest values were recorded by $100 \%$ mineral of the recommended fertilizer unit treatment.

These results are in harmony with those reported by BeykKhurmizi et al., (2015) and Sevinç et al., (2018) on lettuce. Where they reported the increase in leaf mineral (N, P, K, and Ca) contents in case of the application of vermicompost at 5 ton/fadden. Vermicompost promotes minerals uptake (Paul and Bhattacharya 2012; Sabrina et al., 2013; Moghadam et al., 2012; Shadanpour et al., 2011), which led to total $\mathrm{N}(\%)$ increase in spinach (Peyvast et al., 2008), P content in the leaves of maize (Zea mays) (Gutie'rrez-Miceli et al., 2008). Moreover, increasing total nitrogen concentration in the leaves of lettuce plant under these biofertilizer is not accompanied by increasing nitrate accumulation in the plant. Which might be due to the utilization and conversion of nitrogen from the simple form such as nitrate to more complicated one such as proteins and amino acids (BeykKhurmizi et al., 2015).

In this experiment the superior effect of Azotobacter chroococcum was recorded in all plant growth, physical and nutritional parameters followed by the Azospirillum brasilense. This holds true for all concentrations mineral fertilizer and rates of vermicompost used and for the two successive seasons. These results are confirmed by many authors on lettuce and other vegetable plants. Among them are Mariola et al., (2008), Abou El-Magd, et al., (2009), Masarirambi et al., (2012) and Han and Lee, (2015) on lettuce. While Verma et al. (2011) and Subramanian, et al., (2014) confirmed the same results by the application of vermicompost in combination with Azospirillum brasilense on Chrysanthemum morifolium plant. It has been reported that biofertilizers improve plant photosynthetic activity which enhance plant stress tolerance (Chi, et al., 2010) pathogens resistance (Thamer, et al., 2011) and vegetative development (Sahoo et al., 2013). Azotobacter have high nitrogen fixing capacity (Ardakani et al., 2011). It produces antifungal compounds that protects plants from many pathogens (Sahoo et al., 2013). Moreover, Azotobacter produce plant growth promoting vitamins (Revillas, et al., 2000), plant hormones (Abd El -Fattah et al., 2013). On the other hand, Azospirillum brasilense are free-living aerobic bacteria (Sahoo et al., 2014) which promotes plant growth and development (Bhattacharyya, 2012).

\section{Conclusion}

The result of the experiment indicated that the highest growth and yield of lettuce was obtained by using eco-friendly organic fertilizer and biofertilizers than mineral fertilizer. It is well known that biofertilizers can lower the amount of added chemical nitrogen fertilizer to the soil and consequently mitigation of pollution. In addition, the beneficial effects of biofertilizers such as production of organic acids (lowering soil $\mathrm{pH}$ ) and production of plant growth regulators may contribute to a better plant growth and yield through enhancing nutrient uptake. Biofertilizers increased the concentration of simple organic molecules such as carbohydrates, total protein and vitamin $\mathrm{C}$ which played a role in regulation of plant osmosis and consequently better plant growth and yield.

\section{References}

A.O.A.C., 1990. Official methods of analysis of the association of Official analytical chemist's 15 th Ed. Published by the association of official analytical chemists, INC suite 400. 2200 Wilson Boulevard, Arlington, Virginia. 22201 USA.

Abd El-Fattah, D.A., W.E. Ewedab, M.S. Zayed and M.K. Hassaneina, 2013. Effect of carrier materials, sterilization method, and storage temperature on survival and biological activities of Azotobacter chroococcum inoculants. Ann Agric Sci 2013, 58:111-118.

Abdel-Razzak, H.S. and G.A. EI-Sharkawy, 2013. Effect of biofertilizer and humic acid applications on growth, yield, quality and storability of two garlic (Allium sativum L.) cultivars. Asian J. of crop Sci. 5 (1): 48-64.

Abou El-Hassan, S., M. AbdElwanis and M.Z. El-Shinawy, 2017. Application of Compost and Vermicompost as Substitutes for Mineral Fertilizers to Produce Green Beans. Egypt. J. Hort. 44(2):155-163.

Abou El-Magd, M.M., A.A. Abd El-Fattah, and E.M. Selim 2009. Influence of mineral and Organic Fertilization Methods on Growth. J Agric Sci., 5(5): 582-589. 
Abou El-Magd, M.M., M.F. Zaki, S.A. Abo Sedera, and T.T. El-Shorbagy, 2014. Evaluation of five garlic (Allium sativum L.) cultivars under Bio-chemical and mineral fertilization. Middle East J. Agric. Res., 3(4): 926-935.

Adrian, P.L., P.M. Joaquin, and C. Angel, 2012. Vermicompost Application and Growth Patterns of Lettuce (Lactuca sativa L.) Agricultura Tropica ET Subtropica, 45(3): 2012.

Ahmed, S.I., A.A. Hemada and H.S. Toney, 2012. Response of garlic plants to the application of two bio-fertilizers and four mineral nitrogen levels. Minia J. of Agric. Res. \& Develop.

Aira, M., F. Monroy and J. Domínguez, 2007. Earthworms strongly modify microbial biomass and activity triggering enzymatic activities during vermicomposting independently of the application rates of pig slurry. Science of the Total Environment, 385: 252-261.

Ali A.F., E.A. Hassan, E.H. Hamad and W.M.H. Abo-Quta 2017. Effect of Compost, Ascorbic Acid and Salicylic Acid Treatments on Growth, Yield and Oil Production of Fennel Plant. Assiut J. Agric. Sci., 48:139-154.

Alisson, F. T. D., Rodrigo, C. A., Leonardo P. D. B., João C. R. A., José Valdenor D. J. and Márkilla Z. B.-C.2017. Growth and yield of lettuce cultivars under organic fertilization and different environments. Comunicata Scientiae, 8(2): 265-274.

Alper Durak, Ö.A., K.K. İbrahim, I. Rabia, and E.K. Firat 2017. The Effects of Vermicompost on Yield and Some Growth Parameters of Lettuce Turkish Journal of Agriculture - Food Science and Technology, 5(12): 1566-1570.

Alsina, I., L. Dubova, V. Steinberga, and G. Gmizo, 2013. The effect of vermicompost on the growth of radish. Acta Horticulturae, 1013:359-365.

Amiri, H., A. Ismaili, and S.R. Hosseinzadeh, 2017. Influence of vermicompost fertilizer and water deficit stress on morpho-physiological features of chickpea (Cicer arietinum L. cv. Karaj). Compost Science \& Utilization, 25:152-165.

Amoozgar, A., A. Mohammad, and M.R. Sabzalian, 2017. Impact of light-emitting diode irradiation on photosynthesis, phytochemical composition and mineral element content of lettuce cv. Photosynthetica, 55 (1):85-95. doi: 10.1007/s11099-016-0216-8.

Arancon, N.Q., C.A. Edwards, R.M. Atiyeh, and J.D. Metzger, 2004. Effects of vermicompost produced from food waste on the growth and yield of greenhouse peppers. Bioresource Technol., 93: 139144.

Ardakani, M.R., D. Mazaheri, S. Mafakheri, and A. Moghaddam, 2011. Physiol Mol Biol Plants, 17 (2): 181-192.

Azarmi, R., M.T. Giglou, and R.D. Taleshmikail, 2008. Influence of vermicompost on soil chemical and physical properties in tomato (Lycopersicon esculentum) field. African Journal of Biotechnology, 7:2397-2401.

Bajeli, J., S. Tripathi, A. Kumar, and R.K. Upadhyay, 2016. Organic manures a convincing source for quality production of Japanese mint (Mentha arvensis L.). Industrial Crops and Products, 83: 603606.

BeykKhurmizi, A., P. Abrishamchi, A. Ganjeali, and M. Parsa, 2015. Effect of vermicompost on some morphological, physiological and biochemical traits of bean (Phaseolus vulgaris L.) Under salinity stress. J. Plant Nutr., 39:883-893.

Bhattacharyya, P.N., and D.K. Jha, 2012. Plant growth-promoting rhizobacteria (PGPR): emergence in agriculture. World J Microbiol Biotechnol, 28:1327-1350.

Blom-Zandstra, M., J.E.M. Lampe, and F.H.M. Ammerlan, 1988. C and N utilization of two lettuce genotypes during growth under non-varying light conditions and after changing the light intensity. Physiol. Plant, 74(1):147-153.

Bosch, N., J.R. Mart1'nez, and M.L. Pe' rez, 1991. Influence del tipo de abono sobre acumulacio' n de nitratos en vegetales. An. Bromatol. XLIII-2:215-220.

Campitelli, P. and S. Ceppi, 2008. Chemical, physical and biological compost and vermicompost characterization: A chemometric study. Chemometrics and Intelligent Laboratory Systems, 90: 64-71.

Cataldo, D.A., M. Haroon, L.E. Schrader, and V.L. Youngs, 1975. Rapid colorimetric determination of nitrate in plant tissue by nitration of salicylic acid. Commun. Soil Sci. Plant. An. 6: 71-80.

Chaoui, H.I., L.M. Zibilske, and T. Ohno, 2003. Effects of earthworm casts and compost on soil microbial activity and plant nutrient availability. Soil Biology and Biochemistry, 35: 295-302. 
Chapman, H.D. and P.F. Pratt, 1982. Methods of analysis for soil, plant, and water. Priced publication 4034, Univ, of California, Div. Agric. Sci.

Chi, F., P. Yang, F. Han, Y. Jing, and S. Shen, 2010. Proteomic analysis of rice seedlings infected by Sinorhizobium meliloti 1021. Proteomics, 10:1861-1874.

Christopoulou, M., S.R.C. Wo, A. Kozik, L.K. McHale, M.J. Truco, T. Wroblewski, and R.W. Michelmore, 2015. Genome-wide architecture of disease resistance genes in lettuce. G3 Genes Genomes Genet., 5: 2655-2669.

Cooper, A., 1979. The ABC of NFT Grower Books. London, 181.

Dahan, O., A. Babad, N. Lazarovitch, E.E. Russak, and D. Kurtzman, 2014. Nitrate leaching from intensive organic farms to groundwater. Hydro Earth System Sci, 18(1), 333-341.

http://dx.doi. org/10.5194/hess-18-333-2014.

Darzi M.T., M.H.S. Hadi and F. Rejali, 2012. Effects of the application of vermicompost and nitrogen fixing bacteria on quantity and quality of the essential oil in dill (Anethum graveolens). J. Medicinal Plants Res., 6(21): 3793-3799.

Dawa, K.K., E.A.A. Radwan and F.Y. Mansour, 2012. Effect of chicken manure levels, biofertilizers and some foliar application treatments on garlic 1. Plant growth and leaf pigments. J. Plant Production, Mansoura Univ., 3 (3): 571-586.

Domínguez, J., M. Aira, and M.G., Brandón, 2010. Vermicomposting: earthworms enhance the work of microbes. In: H. Insam, I. Franke-Whittle and M. Goberna, (Eds.), Microbes at Work: From Wastes to Resources (pp. 93-114). Springer, Berlin Heidelberg,

Duncan, D.B., 1955. Multiple range and multiple "F" test. Biometrics, 11: 1-42.

El-Behairy, U., 1994. The effect of levels of phosphorus andzinc in the nutrient solution on macro and micronutrientsuptake and translocation in cucumber (Cucumus sativus L.) grown by the nutrient film technique. Ph. D thesis, London Univ., 299.

Eswaran, N. and S. Mariselvi, 2016. Efficacy of Vermicompost on growth and yield parameters of Lycopersicum esculentum (Tomato). International Journal of Scientific and Research Publications, 6: 95-108.

Fawzy, Z.F., Z.S. El-Shal, L. Yunsheng, O. Zhu, and O.M. Sawan, 2012. Response of garlic (Allium sativum L.) plants to foliar spraying of some bio- stimulants under sandy soil condition. J of Appl Sci Res., 8 (2): 770-776.

Frasetya, B., K. Harisman, S. Maulid, and S. Ginandjar, 2019. The effect of vermicompost application on the growth of lettuce plant (Lactuca sativa L.) Journal of Physics: Conference Series 1402 (2019) 033050 IOP Publishing doi:10.1088/1742-6596/1402/3/033050.

Ghosh, M., and A. Devi, 2019. Assessment of crop growth, soil properties and crop yield in an upland acidic soil with inorganic fertilizer blended with organic amendments in summer rice cropping seasons. International Journal of Recycling of Organic Waste in Agriculture 8 (S1):1-9. doi: 10.1007/s40093-019-0252-z.

Gopalakrishnan, S., P. Humayun, S. Vadlamudi, R. Vijayabharathi, R.K. Bhimineni, and O. Rupela, 2012 .Plant growth-promoting traits of streptomyces with biocontrol potential isolated from herbal vermicompost. Biocontrol. Sci. Tech., 22(10):1199-1210.

Gutie'rrez-Miceli, F.A., B. Moguel-Zamudio, M. Abud-Archila, V.F. Gutie'rrez-Oliva, and L. Dendooven, 2008. Sheep manure vermicompost supplemented with a native diazotrophic bacteria and mycorrhizas for maize cultivation. Bioresour. Technol., 99:7020-7026.

Hamerschmidt, I., A. Leonardecz, J.A. Gheller, J.L. Bortolossi, M.J. Franco, N. Harger, and N.R.L. Carvalho, 2013. Manual técnico de olericultura. Curitiba: Emater, 266.

Hammadi F.S., M.T. Darzi, and M.H.S. Hadi, 2014. Influence of Compost and Biofertilizer on yield and essential oil of dill (Anethum graveolens L.) International journal of Advanced Biological and Biomedical Research, 2:446-455.

Han, H.S. and K.D. Lee, 2015. Plant growth promoting rhizobacteria effect on antioxidant status, photosynthesis, mineral uptake and growth of lettuce under soil salinity. Research Journal of Agriculture, 1:210-215.

Hanafy, A. A.H., 1996. Physiological studies on tipburn and nitrate accumulation in lettuce plants. J. Agric. Sci. Mansoura Univ., 21(11):3971-3994.

Hanafy, A. A.H., 1997. Effect of foliar application of some chemicals on sex expression of squash plants. J. Agric. Sci. Mansoura Univ., 22(3):697-717. 
Hanafy, A.A.H., J.F. Mishriky, and M.K. Khalil, 2000. Reducing nitrate accumulation in lettuce (Lactica Sativa L.) plants by using different biofertilizers. Cairo University, Egypt, September, 509-517.

Hasan, M.R., A.K.M.M. Tahsin, M.N. Islam, M.A. Ali, and J. Uddain, 2017. Growth and yield of lettuce (Lactuca Sativa L.) influenced as nitrogen fertilizer and plant spacing. IOSR J. Agric. Vet. Sci., 10: $62-71$.

Hassan. A.H., 2015. Improving growth and productivity of two garlic cultivars (Allium sativum L.) grown under sandy soil conditions. Middle East J. Agric. Res., 4 (2): 332-346.

Heba, M.A., H.S. Salah, S. Sabry, S.H. Mohamed and Sally, Abd El., 2019. The growth, chemical composition and evaluation of antimicrobial activity of Salvia officinalis oil under Partial substitution of mineral NPK fertilizer by bio-fertilizer. Middle East Journal of Agriculture, 08(02):457-468.

Hendawy, S.F., A. Azza, E. El-Din, E. Aziz, and E.A. Omer, 2010. Productivity and oil quality of Thymus vulgaris L. under organic fertilization conditions. Ozean Journal of Applied Sciences, 3(2): 203-216.

IBGE. 2006. Instituto Brasileiro de Geografia e Estatística. Sistema IBGE de recuperação automática (SIDRA). Censo Agropecuário. http://www. sidra.ibge.gov.br

Imsande, J. and B. Touraine, 1994. N. demand and the regulation of nitrate uptake. Plant Physiol. 105:37.

Jackson, M.L., 1973. Soil chemical analysis. Prentice-Hall of India.

Jahan, F.N., A.T.M. Shahjalal, A.K. Paul, H. Mehraj and A.F.M.J. Uddin 2014. Efficiency of vermicompost and conventional compost on growth and yield of cauliflower. Bangladesh Res. Public. J., 1:33- 38.

Khalil, M.K., K.F. Taha, M.A. Nesem, and S.S. Sallam 2019. Effect of chemical fertilization, biofertilizer and thidiazuron on growth and yield of celery (Apium graveolens 1.) plant. az. $\mathrm{j}$. pharms sci., 59: 27-53

Lazcano, C., P. Revilla, R.A. Malvar, and J. Domínguez, 2011. Yield and fruit quality of four sweet corn hybrids (Zea mays) under conventional and integrated fertilization with vermicompost. Journal of the Science of Food and Agriculture. 91(7):1244-53. doi: 10.1002/jsfa.4306. Epub 2011 Feb 15.

Liu, C.W., Y. Sung, B.C. Chen, and H.Y. Lai, 2014. Effects of nitrogen fertilizers on the growth and nitrate content of lettuce (Lactuca sativa L.). Int J Environ Res Public Health, 11(4), 4427-4440. http:// dx.doi.org/10.3390/ijerph110404427.

López, A., G.A. Javier, J. Fenoll, P. Hellin, and P. Flores, 2014. Chemical composition and antioxidant capacity of lettuce: Comparative study of regular-sized (Romaine) and baby-sized (Little Gem and Mini Romaine) types. Journal of Food Composition and Analysis, 33(1): 39-48. http://dx.doi.org/10.1016/j.jfca.2013.10.001.

Lores, M., M. Gómez-Brandón, D. Pérez-Díaz, and J. Domínguez, 2006. Using FAME profiles for the characterization of animal wastes and vermicomposts. Soil Biology and Biochemistry 38, 29932996.

Mahmoud, S.O. and D.A.M. Gad, 2020. Effect of vermicompost as fertilizer on growth, yield and quality of bean plants (Phaseolus vulgaris L.). Middle East Journal of Agriculture Research, 09: 220-226.

Mampholo B.M., M.M.P.S. Martin, and S. Dharini, 2016. Phytochemicals and overall quality of leafy lettuce (Lactuca sativa 1.) Varieties grown in closed hydroponic system J. Food quality, 39:805$8-015$.

Manivannan, S., M. Balamurugan, K. Parthasarathi, G. Gunasekaran, and L.S. Ranganathan, 2009. Effect of vermicompost on soil fertility and crop productivity-beans (Phaseolus vulgaris) J. Environ. Biol., 30(2): 275-281.

Marc, A., S. Zucco, W. Alan, C. She-Kong, P.K. Brian and G.M. Joseph, 2015. Effect of soil type and vermicompost applications on tomato growth. Int J Recycl Org Waste Agricult., 4:135-141.

Mariola, L., G.W. Janina, and K. Katarzyna, 2008. The influence of bio-stimulators on yield and quality of leaf and iceberg lettuce grown under field conditions, Biostimulators. In Modern Agricu LtureVegetable Crops, Zbigniew T. Dabrowsk I, 2008. ISBN 83-89503: 57-63. 
Masarirambi, M.T., P. Dlamini, P.K. Wahome, and T.O. Oseni, 2012. Effects of Chicken Manure on Growth, Yield and Quality of Lettuce (Lactuca sativa 'Taina' Under a Lath House in a SemiArid Sub- of Tropical Environment. American-Eurasian J. Agric. \& Sci., 12(3): 399-406.

Maurya, B.R., V.S. Meena, and O.P. Meena, 2014. Influence of Inceptisol and Alfisol's potassium solubilizing bacteria (KSB) isolates on release of K from Waste mica. Vegetos. 27(1): 181-187.

Meena, O.P., B.R. Maurya and V.S. Meena, 2013. Influence of K-solubilizing bacteria on release of potassium from waste mica. Agriculture for Sustainable Development, 1(1): 53-56.

Meena, V.S., B.R. Maurya, and I. Bahadur, 2014. Potassium solubilization by bacterial strain in Waste mica. Bangladesh Journal of Botany, 43(2): 235-237.

Mehnaz, S., and G. lazarovits, 2006. Inoculation effects of Pseudomonas putida, Gluconacetobacter azotocaptans, and Azospirillum lipoferum on corn plant growth under greenhouse conditions. Microbial Ecol., 51: 326-335.

Moghadam, A.R.L., Z.O. Ardebill, and F. Saidi, 2012 .Vermicompost induced changes in growth and development of Lilium Asiatic hybrid var. Navona. Afr. J. Agric. Res., 7(17):2609-2621.

Moradi R., M.N. Mahallati, P.R. Moghaddam, A. Lakzian, and A. Nezhadali, 2011. The effect of application of organic and biological fertilizers on quantity and quality of essential oil in fennel (Foeniculum vulgare). J. Hortic. Sci., 25(1): 25-33.

Moreira, M.A., C.A.P. dos Santos, A.A.T.F.G.B. Lucas, I.M. de Souza and P.R.A. Viégas, 2014. Lettuce production according to different sources of organic matter and soil cover. Agricultural Sciences, 5 (2): 99-105.

Motsara, M.R. and R.N. Roy, 2008. Guide to laboratory establishment for plant nutrient analysis. Food and agricultural organisation of the United Nations FAO Fertilizer and Plant Nutrition Bulletin. Rome. 219.

Murphy R.J. and J.P. Riley, 1962. A modified single solution method for determination of phosphate in natural waters. Anal. Chim. Acta., 27:31-36.

Mycin, T.R., M. Lenin, G. Selvakumar, and R. Thangadurai, 2010. Growth and nutrient content variation of groundnut Arachis hypogaea L. under vermicompost application. J Exp Sci 1(8):1216.

Pandya, U, Maheshwari, D.K. and Saraf, M. 2014 .Assessment of ecological diversity of rhizobacterial communities in vermicompost and analysis of their potential to improve plant growth. Biologia, 69(8):968-976.

Paul, S. and S.S. Bhattacharya, 2012. Vermicompost water hyacinth enhances growth and yield of marigold by improving nutrient availability in soils of north bank plain of Assam. Res Rev J Agric. Sci. Technol., 2(1):36-46

Peyvast, G., J.A. Olfati, S. Madeni, and A. Forghani, 2008 .Effect of vermicompost on the growth and yield of spinach (Spinacia oleracea L.). J Food Agric Environ 6(1):110-113.

Prasad, M. and T.M. Spiers, 1982. Evaluation of a simple sap nitrate test for some ornamental crops. Proc. 9th Intern. Plant Nutr. Coll England, 2:474-479.

Qiu, W., Z. Wang, C. Huang, B. Chen, and R. Yang, 2014. Nitrate accumulation in leafy vegetables and its relationship with water. J Soil Sci Plant Nutr, 14(4): 761-168. http://dx.doi.org/10.4067/s0718- 95162014005000061.

Rakesh, J., S. Jaswinder, and P.V. Adarsh, 2015. Vermicompost as an effective organic fertilizer and biocontrol agent: effect on growth, yield and quality of plants. Rev Environ Sci Biotechnol., 14:137-159.

Resende, G.M., M.A.R. Alvarenga, J.E. Yuri, and R.J. Souza, 2010. Yield and postharvest quality of winter growing crisphead lettuce as affected by doses of nitrogen and molybdenum. Hortic Bras, 28(4), 441-445. http://dx.doi.org/10.1590/s0102- 05362010000400011.

Sabrina, D.T., M.M. Hanafi, A.W. Gandahi, M.T.M. Mohamed, and N.A.A. Aziz, 2013. Effect of mixed organic-inorganic fertilizer on growth and phosphorous uptake of setaria grass (Setariasplendida). Aust. J. Crop Sci., 7(1):75-83.

Sahoo, R.K., M.W. Ansari, T.K. Dangar, S. Mohanty, and N. Tuteja, 2013. Phenotypic and molecular characterization of efficient nitrogen fixing Azotobacter strains of the rice fields. Protoplasma, doi:10.1007/s00709-013-0547-2. 
Sahoo, R.K., M.W. Ansari, M. Pradhan, T.K. Dangar, S. Mohanty, and N. Tuteja, 2014. Phenotypic and molecular characterization of efficient native Azospirillum strains from rice fields for crop improvement. Protoplasma, doi:10.1007/s00709-013-0607-7.

Santamaria, P., 2006. Nitrate in vegetables, toxicity, content, intake and EC regulation. J Sci Food Agr, 86, 10-17. http://dx.doi.org/10.1002/jsfa.2351.

Sedighe, H., M.R. Naser, and R.D. Hamid, 2014. Effect of planting patterns and vermicompost on yield and yield components in maize and beans intercropping. International journal of Advanced Biological and Biomedical Research, 2(4): 1064-1074.

Sevinç A., E. Funda, Y.S. Açıkgöz, Ç. Ece, and A. Aydın, 2018. Effect of vermicompost on the growth and yield of Lettuce plant (lactuca sativa 1. Var. Crispa)-. International Journal of Plant \& Soil Science.21(1): 1-5, 2018; Article no. IJPSS.37574 ISSN: 2320-7035.

Shadanpour, F., T.A. Mohammadi and M.K. Hashemi, 2011. The effect of cow manure vermicompost as the planting medium on the growth of Marigold. Ann. Biol. Res, 2(6):109-115.

Sharma, A., R.P. Sharma, V. Katoch, and G.D. Sharma, 2017. Influence of vermicompost and split applied nitrogen on growth, yield, nutrient uptake and soil fertility in pole type French bean (Phaseolus vulgaris L.) in an Acid Alfisol. Agricultural Research Communication Centre. Legume Research an International Journal, 1-6.

Sharma, K.C., 2000. Influence of integrated nutrient management on yield and economics in broccoli (Brassica oleracea L. varitalica) cv 'Green Head' plenck under cold temperate conditions.Journal of Vegetable Science, 27 (1): 62-63.

Shirkhodaei M., M.T. Darzi and M.H.S. Hadi, 2014. Influence of vermicompost and biostimulant on the growth and biomass of coriander (Coriandrum sativum L.). Int. J. Adv. Biol. Biomed. Res., 2:706-714.

Snedecor, G.W. and W.G. Cochran, 1982. Statistical Methods. 7 th ed. Iowa State Univ. Press, Iowa, U.S.A.

Stevens, 1974. Ranked lettuce as the 26th according to its nutritive value and the 4th in terms of consumption.

Subramanian, P., K. Kim, R. Krishnamoorthy, S. Sundaram and T. Sa, 2014. Endophytic bacteria improve nodule function and plant nitrogen in soybean on co-inoculation with Bradyrhizobium japonicum MN110. Plant Growth Regul., 76:327-332.

Szwonek, E., 1988. Evaluation of plants nutrition status by fresh index part or sap analysis. Acta Hort. 222:201-206.

Tai, Y.P. and C.T. Young, 1974. Variation in Protein Percentage in Different Portions of Peanut Cotyledons. Crop science, 01: 227-229.

Thamer, S., M. Schädler, D. Bonte, and D.J. Ballhorn, 2011. Dual benefit from a belowground symbiosis: nitrogen fixing rhizobia promote growth and defense against a specialist herbivore in a cyanogenic plant. Plant Soil, 34:1209-1219.

USDA. 2015. National Nutrient Database for Standard Reference Release 28. Retrieved September 6, 2015, from http://ndb.nal.usda.gov/ndb.

Verma, V.C., S.K. Singh, and S. Prakash, 2011. Bio-control and plant growth-promotion potential of siderophore producing endophytic Streptomyces from Azadirachta indica A. Juss. J Basic Microbiol., 51:550-556.

Watanabe F.S. and S.R. Olsen 1965. Test of an ascorbic acid method for determining phosphorus in water and $\mathrm{NaHco}_{3}$ extracts form soil. Soil sci. soc. Am. Proc., 29: 677-678.

Williams, C.M., 2002. Nutritional quality of organic food: Shades of grey or shades of green? Proc. Nutr. Soc. 61:19-24.

Yassen, A.A., M.E. Entsar, and M.Z. Sahar, 2019. The Role of Vermicompost and Foliar Spray of Spirulina Platensis Extract on Vegetative Growth, Yield and Nutrition Status of Lettuce Plant under sandy soil. Research Journal of Agriculture and Biological Sciences, 14(1): 1-7. DOI: 10.22587/rjabs.2019.14.1.1.

Zaki, H.E.M., H.S. Toney and R.M. Bhattacharyya, 2014. Response of two garlic cultivars (Allium sativum $L$.) to inorganic and organic fertilization. Nature and Science; 12(10): 52 -60. 